\title{
Rainfall erosivity mapping over mainland China based on high density hourly rainfall records
}

Tianyu Yue ${ }^{1}$, Shuiqing Yin ${ }^{1}$, Yun Xie ${ }^{1}$, Bofu Yu², Baoyuan Liu ${ }^{1}$

${ }^{1}$ State Key Laboratory of Earth Surface Processes and Resource Ecology, Faculty of Geographical Science, Beijing Normal 5 University, Beijing, 100875, China

${ }^{2}$ Australian Rivers Institute, School of Engineering and Built Environment, Griffith University, Nathan, Queensland, QLD 4111, Australia

Correspondence to: Shuiqing Yin (yinshuiqing@bnu.edu.cn)

Abstract. Rainfall erosivity represents the effect of rainfall and runoff on the average rate of soil erosion. Maps of rainfall

10 erosivity are indispensable for soil erosion assessment using the Universal Soil Loss Equation (USLE) and its successors. To improve current erosivity maps based on daily rainfall data for mainland China, hourly rainfall data from 2381 stations for the period 1951-2018 were collected to generate the $\mathrm{R}$ factor and the 1-in-10-year $\mathrm{EI}_{30}$ maps (available at https://dx.doi.org/10.12275/bnu.clicia.rainfallerosivity.CN.001; Yue et al., 2020). Rainfall data at 1-min intervals from 62 stations (18 stations) were collected to calculate rainfall erosivities as true values to evaluate the improvement of the new $R$

15 factor map (1-in-10-year $\mathrm{EI}_{30}$ map) from the current maps. Both the $\mathrm{R}$ factor and 1-in-10-year $\mathrm{EI}_{30}$ decreased from the southeastern to the northwestern, ranging from 0 to $25300 \mathrm{MJ} \mathrm{mm} \mathrm{ha}^{-1} \mathrm{~h}^{-1} \mathrm{a}^{-1}$ for the $\mathrm{R}$ factor and 0 to $11246 \mathrm{MJ} \mathrm{mm} \mathrm{ha}^{-1} \mathrm{~h}^{-1}$ for the 1-in-10-year $\mathrm{EI}_{30}$. New maps indicated current maps existed an underestimation for most of the southeastern areas and an overestimation for most of the middle and western areas. Comparing with the current maps, the $\mathrm{R}$ factor map generated in this study improved the accuracy from $19.4 \%$ to $15.9 \%$ in the mid-western and eastern regions, from $45.2 \%$ to $21.6 \%$ in the

20 western region, and the 1-in-10-year $\mathrm{EI}_{30}$ map in the mid-western and eastern regions improved the accuracy from $21.7 \%$ to $13.0 \%$. The improvement of the new $\mathrm{R}$ factor map can be mainly contributed to the increase of data resolution from daily data to hourly data, whereas that of new 1-in-10-year $\mathrm{EI}_{30}$ map to the increase of the number of stations from 744 to 2381 . The effect of increasing the number of stations to improve the interpolation seems to be not very obvious when the station density was denser than about $10 \cdot 10^{3} \mathrm{~km}^{2} 1$ station.

\section{Introduction}

Soil erosion has been the major threat to soil health, soil and river ecosystem services in many regions of the world. Soil erosion has on-site impacts, such as the reduction of soil and water, the loss of soil nutrients, the decrease of land quality and food production, as well as off-site impacts, such as excessive sedimentation and water pollution. The reduction of crop production due to erosion has been estimated to be $0.4 \%$ per year on a global scale (FAO, 2019b). Soil erosion models are tools to evaluate the rate of soil loss and can provide policymakers useful information for taking measures in soil and water 
https://doi.org/10.5194/essd-2020-370

Preprint. Discussion started: 1 March 2021

(c) Author(s) 2021. CC BY 4.0 License.

conservation. The Universal Soil Loss Equation (USLE; Wischmeier and Smith, 1965, 1978) and the Revised USLE (RUSLE; Renard, 1997; USDA-ARS, 2013) have been widely used to estimate soil erosion in at least 109 countries over the past 40 years (Alewell et al., 2019). Rainfall erosivity is one of the factors in the USLE and RUSLE to represent the potential ability of rainfall and runoff to affect soil erosion. In the USLE, erosivity of a rainfall event is identified as the EI value, also denoted as $\mathrm{EI}_{30}$, which is the product of the total storm energy (E) and the maximum 30-min intensity ( $\mathrm{I}_{30}$ ) (Wischmeier, 1959). The erosivity factor ( $\mathrm{R}$ factor) in the USLE is the average annual total EI values of all erosive events. To recognize interannual rainfall variability, rainfall data of long periods are required (Wischmeier and Smith, 1978). In the original isoerodent map generated by Wischmeier and Smith (1965), stations with rainfall data of at least 22 years were used. To use the USLE, two additional input parameters are required. One is the seasonal distribution of the $\mathrm{R}$ factor. To acquire soil erodibility factor (K factor) and cover-management factor (C factor), the seasonal distribution of EI (monthly, Wischmeier and Smith, 1965; or half-month percentage of EI, Renard, 1997, Wischmeier and Smith, 1978) were needed. The other is the 1-in-10-year storm EI value needed to compute the support practice factor (P factor) for the contour farming (Renard et al., 1997).

Calculation of the rainfall erosivity factor requires high-resolution rainfall data to compute $\mathrm{E}$ and $\mathrm{I}_{30}$ accurately. In the original study of event rainfall erosivity, the recording-rain-gauge chart was used (Wischmeier and Smith, 1958). Meteorological stations with this type of data are sparsely distributed and the record length is usually quite short. Methods to estimate rainfall erosivity based on more readily available data have been developed widely, such as daily (Angulomartínez and Beguería, 2009; Bagarello and D'Asaro, 1994; Capolongo et al., 2008; Haith and Merrill, 1987; Richardson et al., 1983; Selker et al., 1990; Sheridan et al., 1989; Xie et al., 2016; Yu et al., 1996; Yu and Rosewell, 1996a; Zhang et al., 2002), monthly (Arnoldus, 1977; Ferro et al., 1991; Renard and Freimund, 1994), and annual rainfall (Bonilla and Vidal, 2011; Ferrari et al., 2005; Lee and Heo,

50 2011; Yu and Rosewell, 1996b). Yin et al. (2015) evaluated a number of empirical models to estimate the R factor using rainfall data of temporal resolutions from daily to average annual, and showed that the most accurate prediction was based on data at the highest temporal resolution.

Once values of the erosivity factor is obtained with site observations, spatial interpolation methods can be used to estimate rainfall erosivity for sites without rainfall data based on surrounding sites to produce the erosivity maps or isoerodent maps.

55 Local values of erosivity can be taken from these maps (Wischmeier and Smith, 1978). Erosivity maps are indispensable for regional soil erosion and erosion risk assessments based on USLE-type models (Borrelli et al., 2017; Grimm et al., 2001; Liu et al., 2013; Lu et al., 2001; Panagos et al., 2015). Maps based on spatial interpolation have been widely produced around the world (Borrelli et al., 2016; Klik et al., 2015; Liu et al., 2013; Lu and Yu, 2002; Oliveira et al., 2012; Panagos et al., 2015, 2016, 2017; Qin et al., 2016; Sadeghi et al., 2017; Yin et al., 2019).

60 Recently, Food and Agriculture Organization (FAO) proposed to produce a Global Soil Erosion Map (GSERmap) which encouraged scientists from all over the world to generate their own national level maps making the most of the country knowledge, locally available methods and input data (FAO, 2019a). Rainfall erosivity maps for China were reviewed and relevant information on how they were generated are presented in Table 1, which shows that current $\mathrm{R}$ factor maps for mainland China typically used daily rainfall data from about 500-800 stations (e.g., Zhang et al, 2003; Liu et al., 2013; Qin et al., 2016; 
65 Yin et al., 2019; Liu et al., 2020), which were recorded by simple rain gauges and readily available. However, daily rainfall data are not enough to derive sub-daily intensities, which reduced the accuracy of estimated rainfall erosivity (Yin et al., 2015). Breakpoint data and 1-min data are the best datasets for deriving precipitation intensity and estimating rainfall erosivity. However, 62 stations with 1-min data collected were inadequate for the spatial interpolation of rainfall erosivity over mainland China. More than 2000 stations of hourly data were collected, together with the 62 stations of 1-min data: (a) to develop highprecision maps of the $\mathrm{R}$ factor and 1-in-10-year $\mathrm{EI}_{30}$ over the mainland China; (b) to quantify the improvement of the new erosivity maps in higher temporal resolution and station density and better interpolation method compared to current maps. The study of (Yin et al., 2019) was chosen to represent the latest data had set to estimate the R factor and 1-in-10-year $\mathrm{EI}_{30}$ and related maps. New $\mathrm{R}$ factor and 1-in-10-year $\mathrm{EI}_{30}$ maps were produced in this study may improve the estimation of the soil loss in mainland China.

Table 1: Studies on the mapping of $\mathbf{R}$ factor or daily rainfall erosivity $\left(\mathbf{R}_{\mathrm{d}}\right)$ for or involving China

\begin{tabular}{|c|c|c|c|c|c|}
\hline $\begin{array}{l}\text { Study } \\
\text { Area }\end{array}$ & Period & $\begin{array}{c}\text { Temporal resolution of } \\
\text { precipitation data }\end{array}$ & $\begin{array}{l}\text { No. of stations for } \\
\text { the study area }\end{array}$ & Interpolation method & Reference \\
\hline \multirow{5}{*}{ China } & $1956-1984$ & $\begin{array}{l}\text { Multi-year average of annual, } \\
\text { maximum daily and } \\
\text { maximum hourly }\end{array}$ & 125 & Contour mapping & Wang et al., 1996 \\
\hline & 1971-1998 & Daily & 564 & Kriging & Zhang et al., 2003 \\
\hline & $1960-2009$ & Daily & 590 & Kriging & Liu et al., 2013 \\
\hline & $1951-2010$ & Daily & 756 & $\begin{array}{l}\text { Universal co-kriging with } \\
\text { the aid of the elevation }\end{array}$ & Qin et al., 2016 \\
\hline & $1961-2016$ & Daily & 774 & Ordinary Kriging & Yin et al., 2019* \\
\hline \multirow{3}{*}{ Global } & $1989-2010$ & Annual average & $\begin{array}{c}\text { Gridded } \\
\left(0.5^{\circ} \times 0.5^{\circ}\right)\end{array}$ & - & Naipal et al., 2015 \\
\hline & $\begin{array}{l}\text { 1998-2012 } \\
\text { (in China) }\end{array}$ & Hourly and sub-hourly & 3625 (387 in China) & $\begin{array}{l}\text { Gaussian Process } \\
\text { Regression }\end{array}$ & Panagos et al., 2017 \\
\hline & $\begin{array}{l}1980-1999 \\
2000-2017\end{array}$ & Daily & $\begin{array}{c}30000+(\sim 800 \text { in } \\
\text { China })\end{array}$ & Thin-plate spline smoothing & Liu et al., 2020 \\
\hline
\end{tabular}

* Map of event 1-in-10-year $\mathrm{EI}_{30}$ in China was also generated.

\section{Data and methods}

\subsection{Data}

80 Rainfall data at three temporal resolutions were obtained hourly, daily and 1-min. Hourly data were used to generate maps of $\mathrm{R}$ factor and 1-in-10-year $\mathrm{EI}_{30}$. The evaluation of the effect of station density and interpolation methods on generated maps was also based on the erosivity calculated with hourly data. Daily rainfall data were used to adjust the erosivity estimated by hourly data where the record length was short. Data at 1-min interval were used in two ways. One was to calculate the R factor as true values to evaluate the effect of temporal resolution on erosivity estimation along in comparison to the hourly and the daily 
https://doi.org/10.5194/essd-2020-370

Preprint. Discussion started: 1 March 2021

(c) Author(s) 2021. CC BY 4.0 License.

(c) (i)

85 rainfall data. The other is to develop an exponential model for estimating $\mathrm{R}$ factor with the mean annual precipitation. The coefficient of the model was used for adjusting the R factor based on hourly data of shorter periods.

Rainfall data at 1-hour intervals from 2381 meteorological stations over mainland China (Fig. 1) were collected and quality controlled by the National Meteorological Information Center of China Meteorological Administration. The period of the data was from 1951 to 2018. The start year of the data varied because data collection commenced in different years. Observation was suspended in the snowy season, which resulted in some missing months in winter for station in the northern part of China. There were 932 (39\%) stations with data for the whole year, 550 (23\%) stations from April to October and 421 (18\%) stations from May to September.

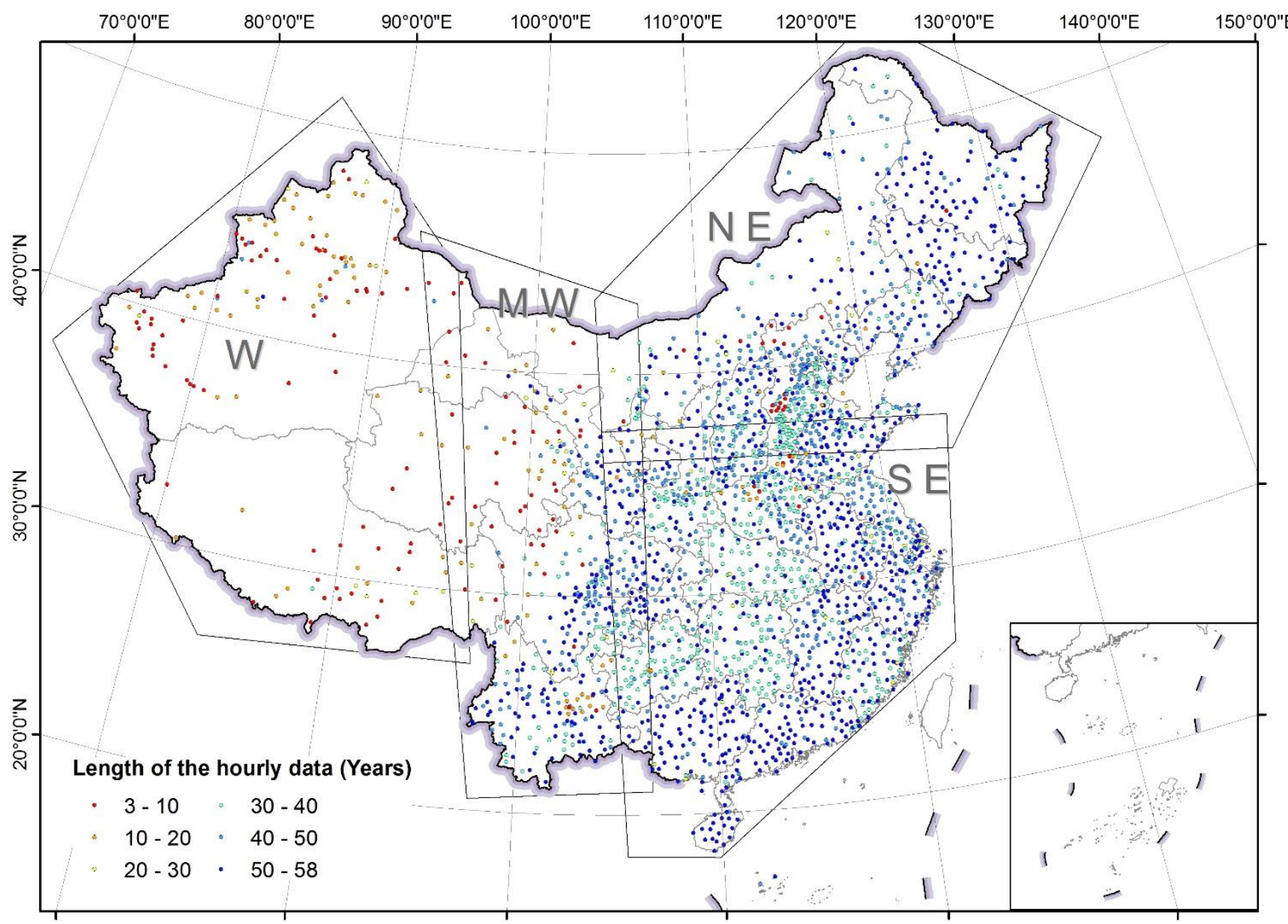

Figure 1: Spatial distribution of stations with hourly rainfall data and the length of the data. Western, Mid-western, Northeastern and Southeastern regions were abbreviated as W, MW, NE and SE, respectively.

The missing data were handled according to the following criteria: (a) a day with more than 4 missing hours was defined as a missing day; (b) a month with more than 6 missing days was defined as a missing month; (c) a year with any missing month in its wet-season was defined as a missing year. The wet-season for stations north of $32^{\circ} \mathrm{N}$ was from May to September, and 
https://doi.org/10.5194/essd-2020-370

Preprint. Discussion started: 1 March 2021

(c) Author(s) 2021. CC BY 4.0 License.

(c) (1)

for those south of $32^{\circ} \mathrm{N}$ was from April to October. Missing years were removed and missing hours in the remaining effective

100 years were input in two categories: (a) the missing period is followed by a non-zero record, which recorded the accumulated rainfall amount in the missing period based on data notes; (b) the missing period is followed by zero. In the first case, each missing hour and the following non-zero hour were assigned the average value of the non-zero record in these hours. For the second case, the missing hours were input as zero value.

The daily data were obtained for the same 2381 stations over the period of 1951-2014 (Fig. 1), and precipitation was measured

105 with simple rain gauges. The data were also collected and quality controlled by the National Meteorological Information Center of China Meteorological Administration. Daily data were collected all year round and the number of effective years ranged from 18 to 54 years. Most of the stations (88\%) have data of more than 50 years. An effective year of the daily data was defined as there is no more than one missing month in the year, and a missing month was defined as there are more than 6 missing days in the month. The missing records in the effective years were input as zero value.

110 Data at 1-min intervals were collected from 62 stations in mainland China (Fig. 2; and were used in Yue et al., 2020). Data from station No. 1-18 have effective years of 29-40 and cover the period of 1961(1971)-2000. Data from stations No. 19-62 have effective years of 2-12 and cover the period of 2005-2016. The missing data in the effective years were assumed to be zero. 
https://doi.org/10.5194/essd-2020-370

Preprint. Discussion started: 1 March 2021

(c) Author(s) 2021. CC BY 4.0 License.

(c) (1)

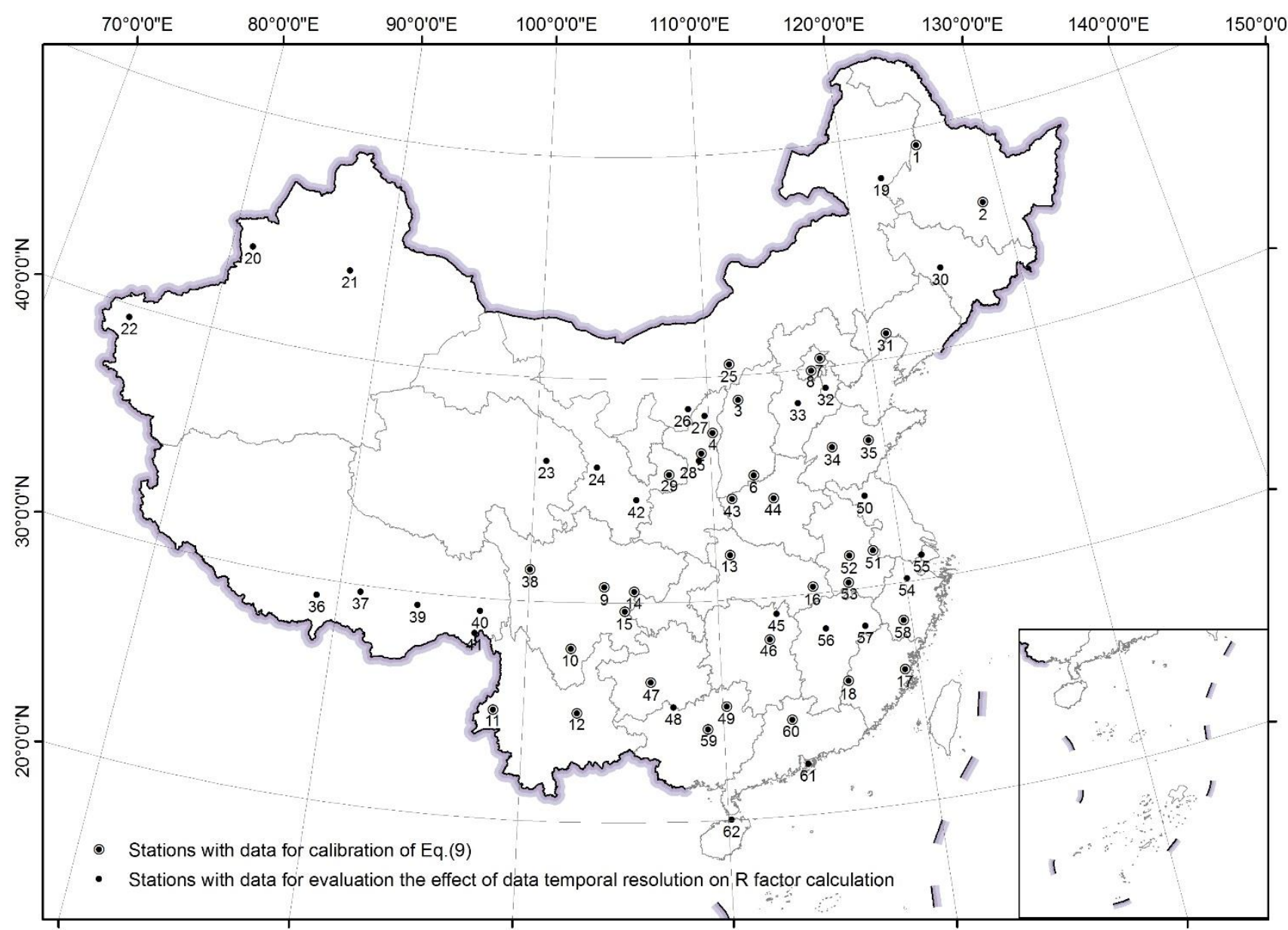

Figure 2: Spatial distribution of the stations with 1-min rainfall data

115

The R factor map from Panagos et al. (2017) shown in the discussion part of this study was from the global rainfall erosivity dataset published by Joint Research Centre - European Soil Data Centre (ESDAC).

\subsection{Rainfall erosivity for stations}

Hourly rainfall data were first separated into rainfall storms. A continuous period of $>=6$ hours of non-precipitation was regarded as the separation of two rainfall storms (Wischmeier and Smith, 1978). Storms with the amount of $>=12 \mathrm{~mm}$ were defined as erosive events (Xie et al., 2000), and were used to calculate the rainfall erosivity factors.

Event rainfall erosivity $\mathrm{EI}_{30}\left(\mathrm{MJ} \mathrm{mm} \mathrm{ha}^{-1} \mathrm{~h}^{-1}\right)$ was the product of the total storm energy $\mathrm{E}\left(\mathrm{MJ} \mathrm{ha}^{-1}\right)$ and the maximum 30-min intensity $\mathrm{I}_{30}\left(\mathrm{~mm} \mathrm{~h}^{-1}\right)$. The maximum 1-hour intensity $\mathrm{H}_{60}\left(\mathrm{~mm} \mathrm{~h}^{-1}\right)$ was obtained in this study:

$\mathrm{E} H_{60}=E \cdot H_{60}$,

$125 \mathrm{E}=\sum_{r=1}^{l}\left(e_{r} \cdot P_{r}\right)$, 
$e_{r}=0.29\left[1-0.72 \exp \left(-0.082 i_{r}\right)\right]$,

where $r=1,2, \ldots, l$ means that a storm could be divided into $l$ periods or a storm lasted for $l$ hours, $e_{r}$ the unit energy (energy per mm of rainfall, $\left.\mathrm{MJ} \mathrm{ha}^{-1} \mathrm{~mm}^{-1}\right), P_{r}$ the amount $(\mathrm{mm})$, and $i_{r}$ the intensity $\left(\mathrm{mm} \mathrm{h}^{-1}\right)$ of the $r^{\text {th }}$ hour (USDA-ARS, 2013).

The $\mathrm{R}$ factor $\left(\mathrm{R}_{\text {hour }}, \mathrm{MJ} \mathrm{mm} \mathrm{ha} \mathrm{a}^{-1} \mathrm{~h}^{-1} \mathrm{a}^{-1}\right)$ was the mean annual rainfall erosivity and was obtained by multiplying the $\mathrm{R}$ factor from hourly data $\left(\mathrm{R}_{h}\right)$ and the conversion factor 1.871 (Yue et al., 2020):

$R_{h}=\frac{1}{N} \sum_{i=1}^{N} \sum_{j=1}^{m}\left(E H_{60}\right)_{i j}$,

$R_{\text {hour }}=1.871 \cdot R_{h}$,

where $i=1,2, \ldots, N$ means there are $N$ effective years, and $\mathrm{j}=1,2, \ldots, m$ means there are $m$ erosive rainfall storms in the $i^{\text {th }}$ year.

135 The 1-in-10-year $\mathrm{EI}_{30}$ was obtained by calibrating the generalized extreme value (GEV) distribution, and the parameters of the model were estimated using L-moments method (Hosking, 1990). The GEV distribution is a family of probability distributions of Gumbel, Fréchet and Weibull. and can be denoted as $\mathrm{G}(\mu, \sigma, \xi)$ with parameters $\mu$ (location), $\sigma$ (scale), and $\xi$ (shape) (Coles, 2001):

$\mathrm{G}(\mathrm{z})=\exp \left\{-\left[1+\xi\left(\frac{x-\mu}{\sigma}\right)\right]^{-1 / \xi}\right\}\{x: 1+\xi(x-\mu) / \sigma>0\}$,

140 where $x$ was the annual maximum storm $\mathrm{EI}_{30}\left(\mathrm{MJ} \mathrm{mm} \mathrm{ha}^{-1} \mathrm{~h}^{-1}\right),-\infty<\mu<\infty, \sigma>0$ and $-\infty<\xi<\infty$. The extreme quantiles of the annual maximum $\mathrm{EI}_{30}\left(X_{p}\right)$ were then obtained by inverting Eq. (6):

$X_{p}=\left\{\begin{array}{c}\mu-\frac{\sigma}{\xi}\left[1-\{-\log (1-p)\}^{-\xi}\right], \text { for } \xi \neq 0 \\ \mu-\sigma \log \{-\log (1-p)\}, \text { for } \xi=0\end{array}\right.$,

where $\mathrm{G}\left(X_{p}\right)=1-p$. The 1-in-10-year $\mathrm{EI}_{30}$, was the value of $X_{\mathrm{p}}$ when $p$ was 1/10. The computed 1-in-10-year $\mathrm{EI}_{30}$ using hourly rainfall data was then multiplied by the conversion factor of 1.489 (Yue et al., 2020).

145 Due to the variability of rainfall erosivity, stations with less than 22 effective years should be excluded (Wischmeier and Smith, 1978). However, stations in western China have limited effective years (Fig. 1). Once stations with less than 22 effective years are removed, the western stations would be too sparse, which would reduce the accuracy of the rainfall erosivity map. To fill the gap of the insufficient years, daily rainfall data observed by simple rainfall gauges (usually have longer periods) of these stations were used.

150 The calculation of the R factor considered the following two cases: (1) The effective years of hourly data were no less than those of daily data (37\% of the stations); (2) The effective years of hourly data were less than those of daily data (63\% of the stations). In the first case, the R factor was calculated directly by hourly data with Eq. (1-5). In the second case, the R factor was firstly calculated by hourly data with Eq. (1-5), then adjusted by the mean annual rainfall calculated by daily data (Zhu and $\mathrm{Yu}, 2015)$ :

$155 \quad R_{\text {hadj }}=R_{\text {hour }}\left(\frac{P_{\mathrm{d}}}{P_{h}}\right)^{1.481}$, 
https://doi.org/10.5194/essd-2020-370

Preprint. Discussion started: 1 March 2021

(c) Author(s) 2021. CC BY 4.0 License.

(c) (i)

where $\mathrm{R}_{\text {hadj }}$ was the adjusted $\mathrm{R}$ factor, $\mathrm{R}_{\text {hour }}$ was the estimated $\mathrm{R}$ factor using hourly rainfall data, $\mathrm{P}_{d}$ was the mean annual precipitation of longer period (period of the daily data), and $\mathrm{P}_{h}$ was the mean annual precipitation of shorter period (period of the hourly data).

The exponent 1.481 was calibrated with a power function (Eq. 9) of the mean annual precipitation and rainfall erosivity using

160 1-min and daily rainfall data of 35 stations in China (Fig. 2). The 1-min and daily data share periods of more than 10 years for these 35 stations.

$R_{\min }=0.156 \cdot P_{m}^{1.481}$,

where $\mathrm{R}_{\min }$ was the $\mathrm{R}$ factor $\left(\mathrm{MJ} \mathrm{mm} \mathrm{ha}^{-1} \mathrm{~h}^{-1} \mathrm{a}^{-1}\right)$, and $\mathrm{P}_{m}$ was the mean annual precipitation $(\mathrm{mm})$.

$\mathrm{R}$ factor based on 1-min rainfall data was calculated using Eq. (10-11):

$R_{\min }=\frac{1}{N} \sum_{i=1}^{N} \sum_{j=1}^{m}\left(E I_{30}\right)_{i j}$

$\mathrm{E}_{30}=E \cdot I_{30}$,

where $\mathrm{I}_{30}$ was the maximum continuous 30-min intensity. Total storm energy (E) was obtained also using methods from RUSLE2 as Eq. (2-3) with a time increment of 1 min.

Calculation of the 1-in-10-year $\mathrm{EI}_{30}$ also considered two cases: (1) The effective years of the hourly data were no less than 22

170 years (89\% of the stations) and the 1-in-10-year $\mathrm{EI}_{30}$ was estimated by hourly data with Eqs. (6-7); (2) The effective years of the hourly data were less than 22 years, but those of the daily data were no less than 22 years (11\%), the 1-in-10-year EI ${ }_{30}$ was estimated by daily data as follows. Firstly, daily rainfall erosivity was obtained by the following equation developed by Xie et al. (2016):

$R_{\text {daily }}=\alpha P_{\text {daily }}^{1.7265}$,

175 where $\mathrm{P}_{\text {daily }}$ was the daily precipitation $(\geq 10 \mathrm{~mm}$ ), parameter $\alpha$ was 0.3937 in the warm season (May to September), and 0.3101 in the cold season (October to April). Secondly, the 1-in-10-year daily erosivity was obtained by calibrating the GEV distribution parameters as Eq. (6-7) and the $x$ in the functions was replaced by the annual maximum daily erosivity. Finally, the 1-in-10-year daily erosivity from daily data was multiplied by a conversion factor of 1.17 to correct the 1-in-10-year daily erosivity to approximate the actual event 1-in-10-year $\mathrm{EI}_{30}$ from 1-min data (Yin et al., 2019). The record length was 22 to 29 for $16(0.7 \%)$ stations, 30 to 39 for 44 (1.8\%) stations, 40 to 49 for 216 stations (9.1\%) stations, more than 50 for $2105(88.4 \%)$ stations when these adjustments were made.

\subsection{Spatial interpolation and cross validation}

Since there is a good correlation between erosivity factor and the mean annual precipitation, the erosivity maps were obtained using the method of Universal Kriging with the annual rainfall as a co-variable. The annual average rainfall was computed using daily rainfall data of the stations and was firstly interpolated using Ordinary Kriging, and the results were used to conduct Universal Kriging. Both the mean annual precipitation and the erosivity factors were interpolated first for each region 
https://doi.org/10.5194/essd-2020-370

Preprint. Discussion started: 1 March 2021

(c) Author(s) 2021. CC BY 4.0 License.

separately (Fig. 1; Li et al., 2014), and then combined to obtain annual precipitation and erosivity maps over China. Buffer areas were used to avoid the discontinuity in the boundary areas following Li et al. (2014).

To evaluate the efficiency of interpolation models, a leave-one-out cross-validation method was applied in each region. Symmetric mean absolute percentage error (sMAPE) and Nash-Sutcliffe model efficiency coefficient (NSE) were used for the assessment:

$\operatorname{sMAPE}=\frac{1}{n} \sum_{i=1}^{n}\left|\frac{F_{i}-A_{i}}{\left(F_{i}+A_{i}\right) / 2}\right| \times 100 \%$,

$\mathrm{NSE}=1-\frac{\sum_{i=1}^{n}\left(F_{i}-A_{i}\right)^{2}}{\sum_{i=1}^{n}\left(A_{i}-\overline{\mathrm{A}_{l}}\right)^{2}}$,

where $n$ was the number of stations, $F_{i}$ was the predicted value at the position of the $\mathrm{i}^{\text {th }}$ station using data from surrounding stations, $A_{i}$ was the true value at the $\mathrm{i}^{\text {th }}$ station.

\subsection{The evaluation of the improvement on the accuracy of the erosivity maps}

Current erosivity mapping at national scale in mainland China usually uses daily rainfall data from more than 700 stations. The R factor and 1-in-10-year $\mathrm{EI}_{30}$ maps of Yin et al. (2019) were taken as references to evaluate the improvement in the accuracy of the erosivity maps generated in this study. To compare the accuracy of the erosivity maps of this study and those of Yin et al. (2019), true values from 1-min data using Eq. (10-11) for 62 stations were used to evaluate the improvement of $R$ factor and those from 1-min data for 18 stations (No.1-18; Fig. 2Figure 2) with more than 22 years were used to evaluate the 1-in-10-year $\mathrm{EI}_{30}$. The values extracted from the two erosivity maps for these stations were compared with the true values calculated with 1-min data. Relative error $(\%)$ for each station was calculated as follows:

$R E_{i j}=\frac{R_{i j}-\left(R_{\min }\right)_{i}}{\left(R_{\min }\right)_{i}} \times 100 \%$,

where $\left(R_{\min }\right)_{i}$ is the true value calculated from 1 -min data, $i=1,2, \ldots, 62(18) ; R_{i j}$ was the value extracted from the erosivity map of this study and that of Yin et al. (2019); $j=1,2,3,4$ represents $\mathrm{R}$ factor and 1-in-10-year $\mathrm{EI}_{30}$ maps for the two studies; $\mathrm{RE}_{i j}$ was the relative error $(\%)$ of the $\mathrm{R}$ factor or 1-in-10-year $\mathrm{EI}_{30}$ of the $i_{\text {th }}$ station on the $j_{\mathrm{th}}$ map. Considering that the absolute values of RE would be high for stations with smaller $\mathrm{R}$ factor values, the relative error of the entire map was expressed as the median absolute value of the RE for all the stations.

210 The erosivity maps in this study used a different procedure as in Yin et al. (2019) mainly in three areas: (1) temporal resolution (hourly vs. daily); (2) number of stations (2381 stations vs. 744 stations); (3) interpolation method (Universal Kriging vs. Ordinary Kriging).

To evaluate the effect of the temporal resolution on the calculated $\mathrm{R}$ factor and 1-in-10-year $\mathrm{EI}_{30}$, hourly and daily rainfall data with the same period as the 1-min data at the 62 stations were used. $\mathrm{R}$ factors from hourly data were based on Eq. (1-5), those 215 from daily rainfall data were based on Eq. (12), and those from 1-min data were based on Eq. (10-11). The 1-in-10-year EI 30 were all calculated by calibrating GEV distribution using Eq. (6-7). Erosivity factors from 1-min data can be regarded as the true value. The relative error was computed for evaluating accuracy. 
https://doi.org/10.5194/essd-2020-370

Preprint. Discussion started: 1 March 2021

(c) Author(s) 2021. CC BY 4.0 License.

(c) (i)

To evaluate the effect of station density, hourly data from 774 stations (used in Yin et al. (2019)) and from 2381 stations (used in this study) were used to generate two separate erosivity maps. $\mathrm{R}$ factor and 1-in-10-year $\mathrm{EI}_{30}$ values were compared using leave-one-out cross validation method region by region. The sMAPE was calculated for accuracy assessment.

To evaluate the effect of interpolation methods, Ordinary Kriging and Universal Kriging with the mean annual rainfall as the co-variable was applied for the $\mathrm{R}$ factor and 1-in-10-year $\mathrm{EI}_{30}$ computed using hourly data from 2381 stations. Both interpolation methods were applied to each of four different regions as shown in Fig. 1 and leave-one-out cross validation results were compared. The sMAPE was also calculated to evaluate the accuracy of interpolated values.

\section{Results}

\subsection{Accuracy evaluation on erosivity maps}

Taking erosivity maps ( $\mathrm{R}$ factor and 1-in-10-year $\mathrm{EI}_{30}$ ) generated by Yin et al. (2019) as references, this study shows a certain improvement in accuracy (Fig. 3; Table 2). For the R factor, the values in the map of Yin et al. (2019) were underestimated where the $\mathrm{R}$ factor was relatively high, and overestimated where the $\mathrm{R}$ factor was relatively low. The improvement was particularly noticeable for western China $\left(\mathrm{R}<1000 \mathrm{MJ} \mathrm{mm} \mathrm{ha}^{-1} \mathrm{~h}^{-1} \mathrm{a}^{-1}\right)$ and the southeastern coastal region $(\mathrm{R}>10000 \mathrm{MJ}$ $\left.m m \mathrm{ha}^{-1} \mathrm{~h}^{-1} \mathrm{a}^{-1}\right)$.

Relative errors of the two maps at the 62 stations are shown in Fig. 4 (a) and (b). Those with the relative error of more than $100 \%$ were all in the western region. The median values of the absolute RE in Mid-western (MW), Northeastern (NE) and Southeastern (SE) regions were 15.9\% and 19.4\% for maps in this study and Yin et al. (2019), indicating an improvement of $2353.4 \%$. Those in Western (W) region were $21.6 \%$ and $45.2 \%$, respectively, and indicating an improvement of $23.6 \%$. For 1 -in10-year $\mathrm{EI}_{30}$, the median values of the absolute RE were $13.0 \%$ for maps from this study and $21.7 \%$ for Yin et al. (2019), indicating an improvement of $8.7 \%$ in the mid-western and eastern regions. The evaluation on the 1-in-10-year $\mathrm{EI}_{30}$ map didn't cover the western region where there were no 1-min data with enough effective years to estimate return level. 
https://doi.org/10.5194/essd-2020-370

Preprint. Discussion started: 1 March 2021

(c) Author(s) 2021. CC BY 4.0 License.
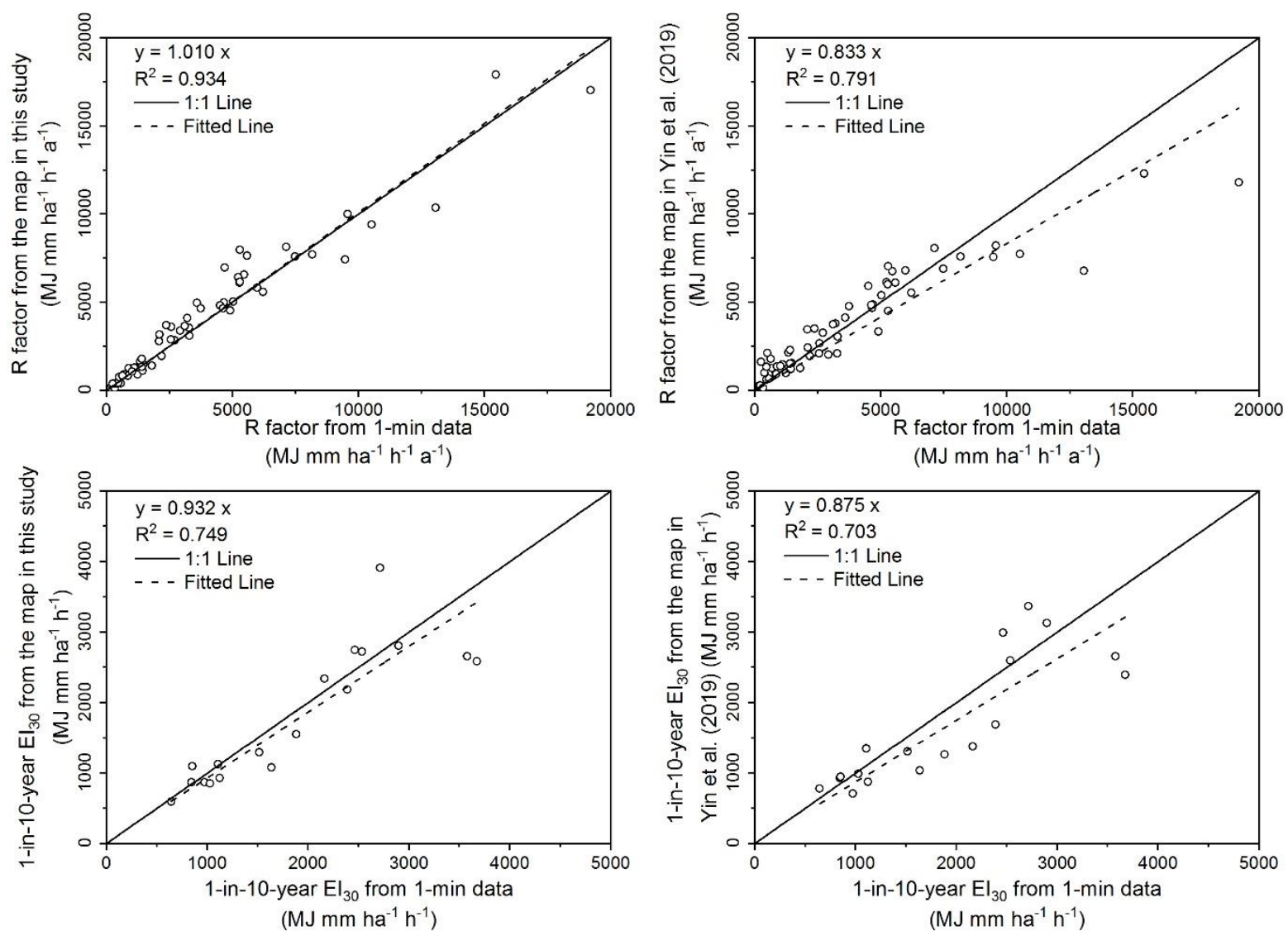

240 Figure 3: Comparison of the $\mathbf{R}$ factors and 1-in-10-year EI $\mathbf{I}_{30}$ extracted from the maps and the true value. The graphs on the left were the evaluation of the maps generated in this study, and those on the right were the evaluation of the maps generated by Yin et al. (2019) 
https://doi.org/10.5194/essd-2020-370

Preprint. Discussion started: 1 March 2021

(c) Author(s) 2021. CC BY 4.0 License.
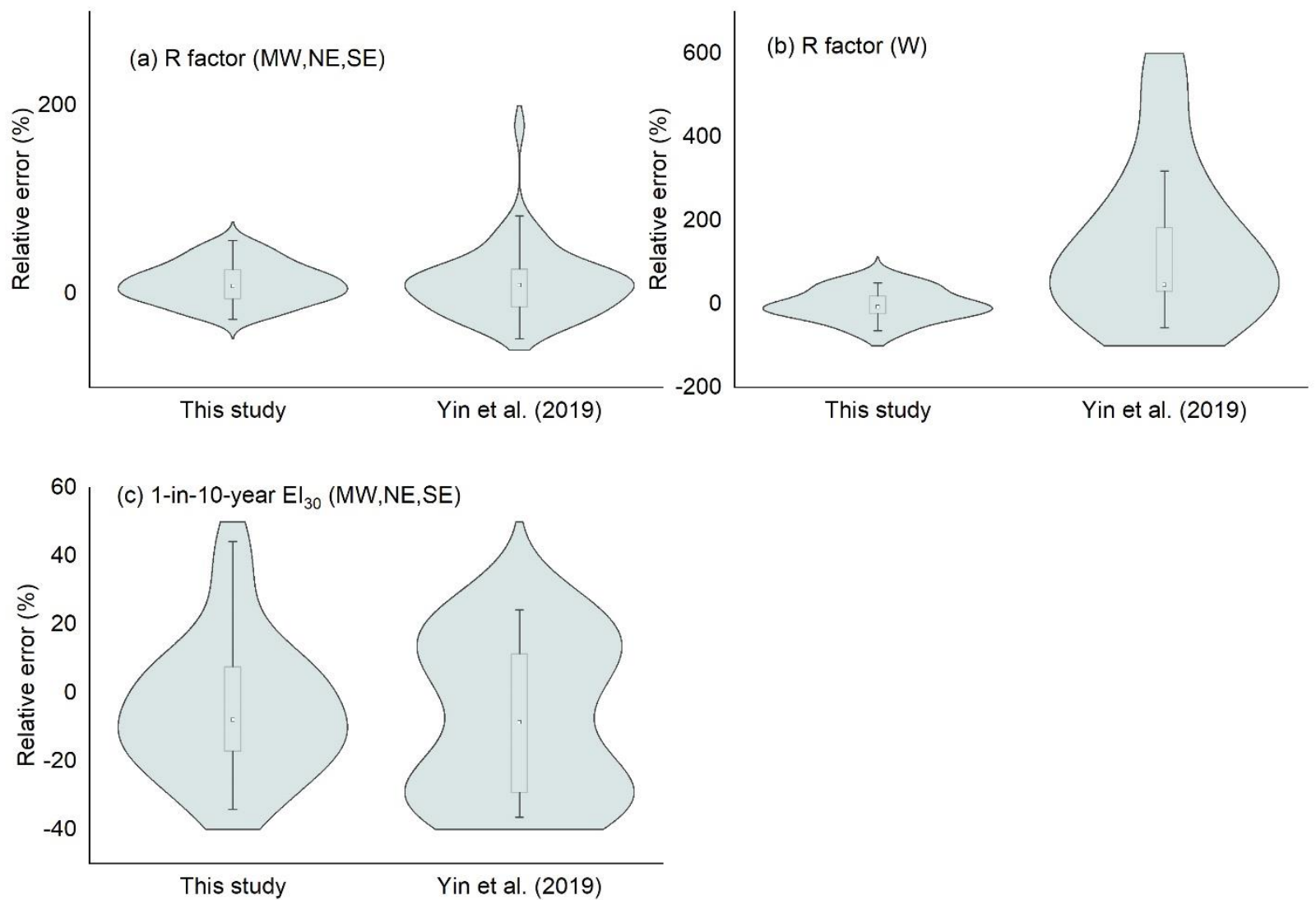

Figure 4: The relative errors of the $\mathrm{R}$ factors (a for region $\mathrm{MW}, \mathrm{NE}, \mathrm{SE}$; $b$ for region W) and 1-in-10-year EI30 (c for region ME,

NE, SE) extracted from the maps

Table 2: The statistical characteristics of the relative errors of the erosivity factors from the maps

\begin{tabular}{|c|c|c|c|c|c|c|}
\hline & \multicolumn{4}{|c|}{$\mathrm{R}$ factor } & \multirow{2}{*}{\multicolumn{2}{|c|}{$\begin{array}{c}\text { 1-in-10-year EI } 30 \\
\mathrm{MW}, \mathrm{NE}, \mathrm{SE}\end{array}$}} \\
\hline & \multicolumn{2}{|c|}{ MW, NE, SE } & \multicolumn{2}{|c|}{$\mathrm{W}$} & & \\
\hline & This study & Yin et al. (2019) & This study & $\begin{array}{c}\text { Yin et al. } \\
(2019)\end{array}$ & This study & Yin et al. (2019) \\
\hline 25 th percentile & $6.2 \%$ & $10.5 \%$ & $9.3 \%$ & $29.9 \%$ & $7.5 \%$ & $11.1 \%$ \\
\hline Median & $15.9 \%$ & $19.4 \%$ & $21.6 \%$ & $45.2 \%$ & $13.0 \%$ & $21.7 \%$ \\
\hline
\end{tabular}


https://doi.org/10.5194/essd-2020-370

Preprint. Discussion started: 1 March 2021

(c) Author(s) 2021. CC BY 4.0 License.

\subsection{Erosivity maps and changes comparing with the previous study}

250 The $\mathrm{R}$ factor generally decreased from the southeastern part to the northwestern part of China (Fig. 5a), ranging from 0 to $25300 \mathrm{MJ} \mathrm{mm} \mathrm{ha}{ }^{-1} \mathrm{~h}^{-1} \mathrm{a}^{-1}$. The map of 1-in-10-year $\mathrm{EI}_{30}$ shows a similar spatial pattern with that of the R factor (Fig. 5b), ranging from 0 to $11246 \mathrm{MJ} \mathrm{mm} \mathrm{ha}^{-1} \mathrm{~h}^{-1}$. Zero $\mathrm{R}$ factor value is found at Turpan, Xinjiang Province, where the mean annual rainfall is only $7.8 \mathrm{~mm}$. The maximum of the $\mathrm{R}$ factor (more than $20000 \mathrm{MJ} \mathrm{mm} \mathrm{ha}^{-1} \mathrm{~h}^{-1} \mathrm{a}^{-1}$ ) is located in the southern part of the Guangxi and Guangdong provinces, along the South China Sea, where the mean annual rainfall is more than $2500 \mathrm{~mm}$.

In addition to the overall trend, some local scale characteristics could be identified in the maps. Taking the R factor map as an example, in the western region, the wetter region in northwestern China was located in the west of Dzungaria Basin and along the Tianshan Mountain, which could be captured on the map.

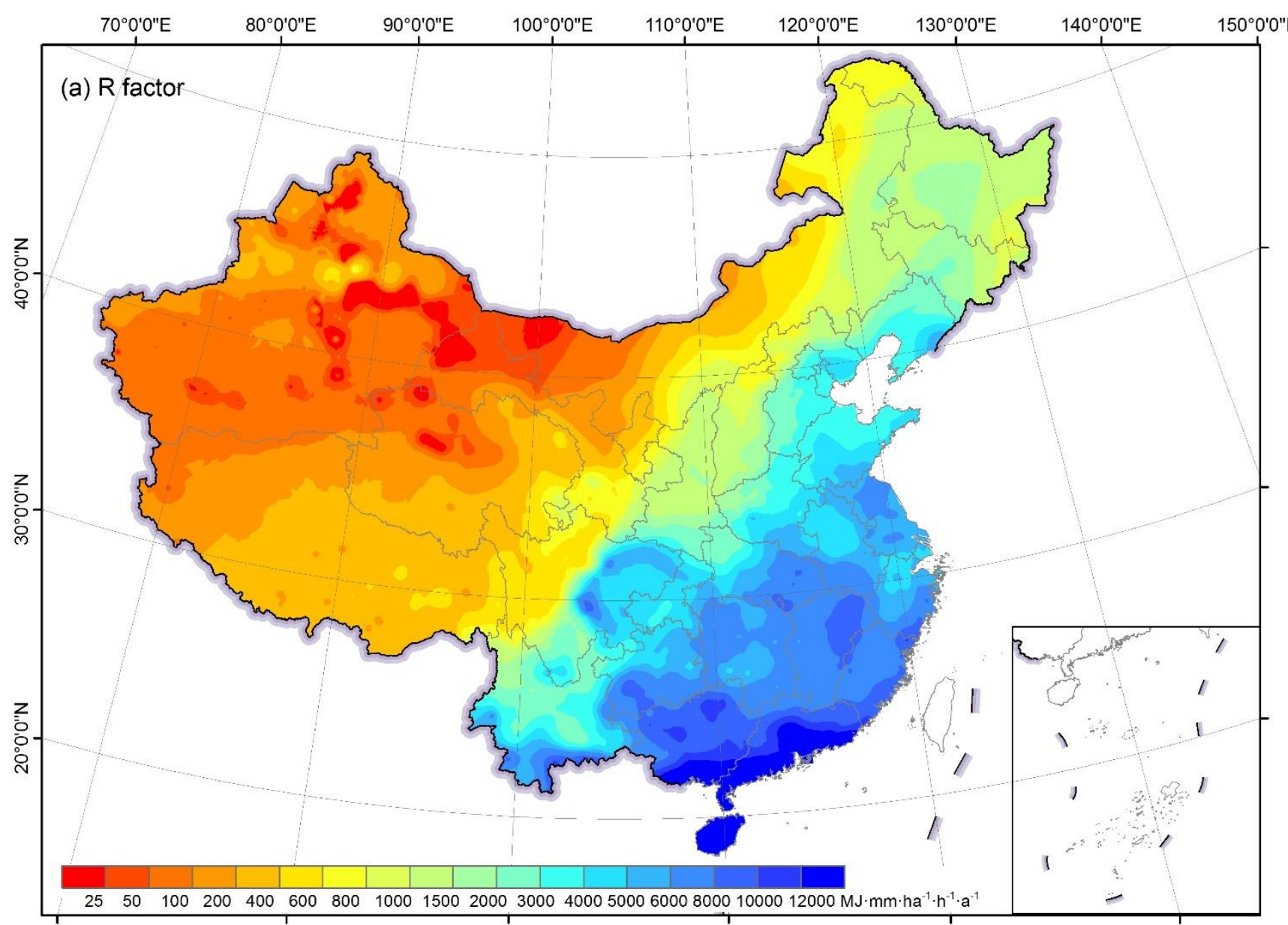


https://doi.org/10.5194/essd-2020-370

Preprint. Discussion started: 1 March 2021

(c) Author(s) 2021. CC BY 4.0 License.

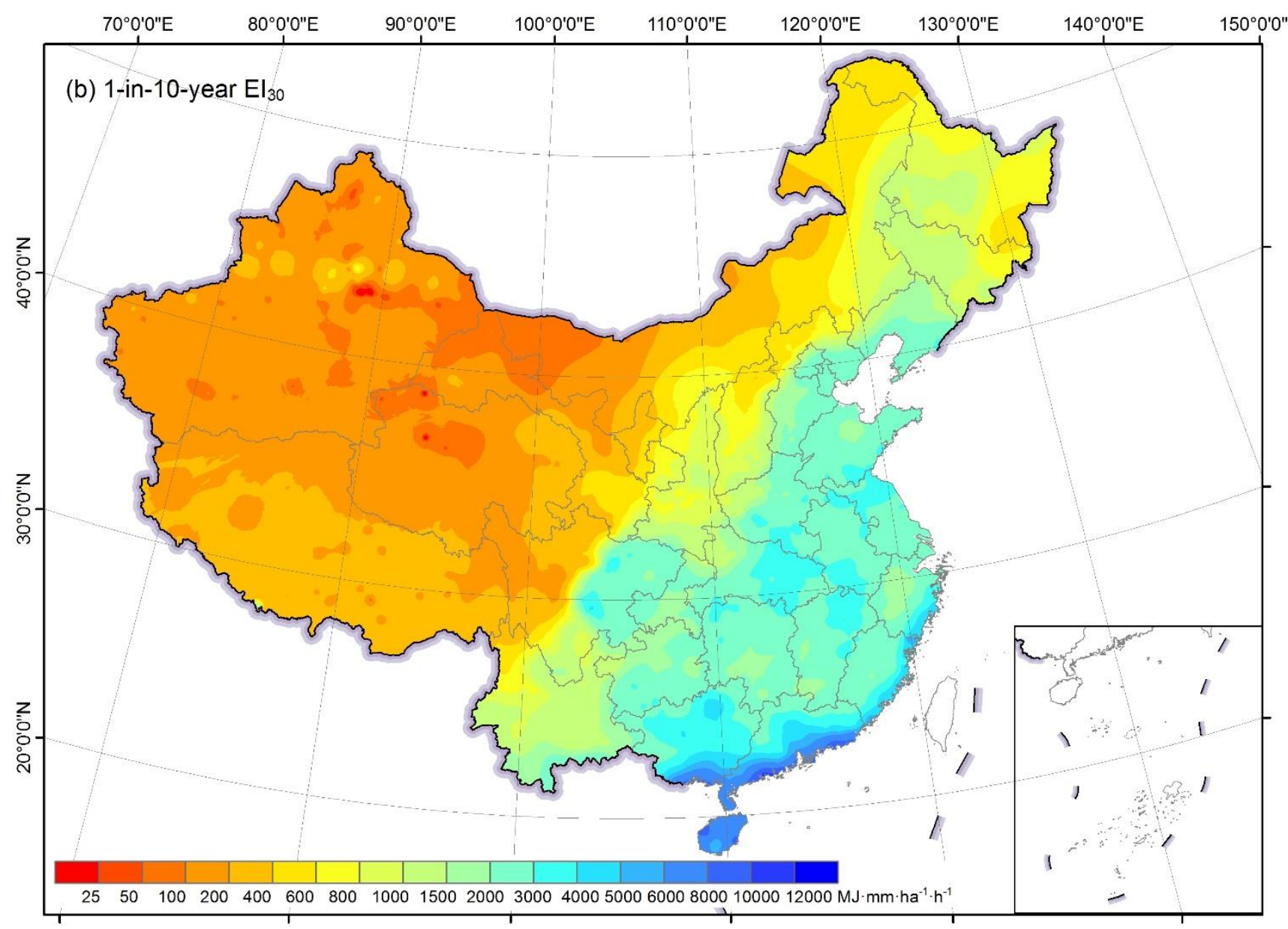

Figure 5: $\mathrm{R}$ factor(a) and 1-in-10-year EI30(b) over mainland China based on hourly data from 2381 stations 
https://doi.org/10.5194/essd-2020-370

Preprint. Discussion started: 1 March 2021

(c) Author(s) 2021. CC BY 4.0 License.

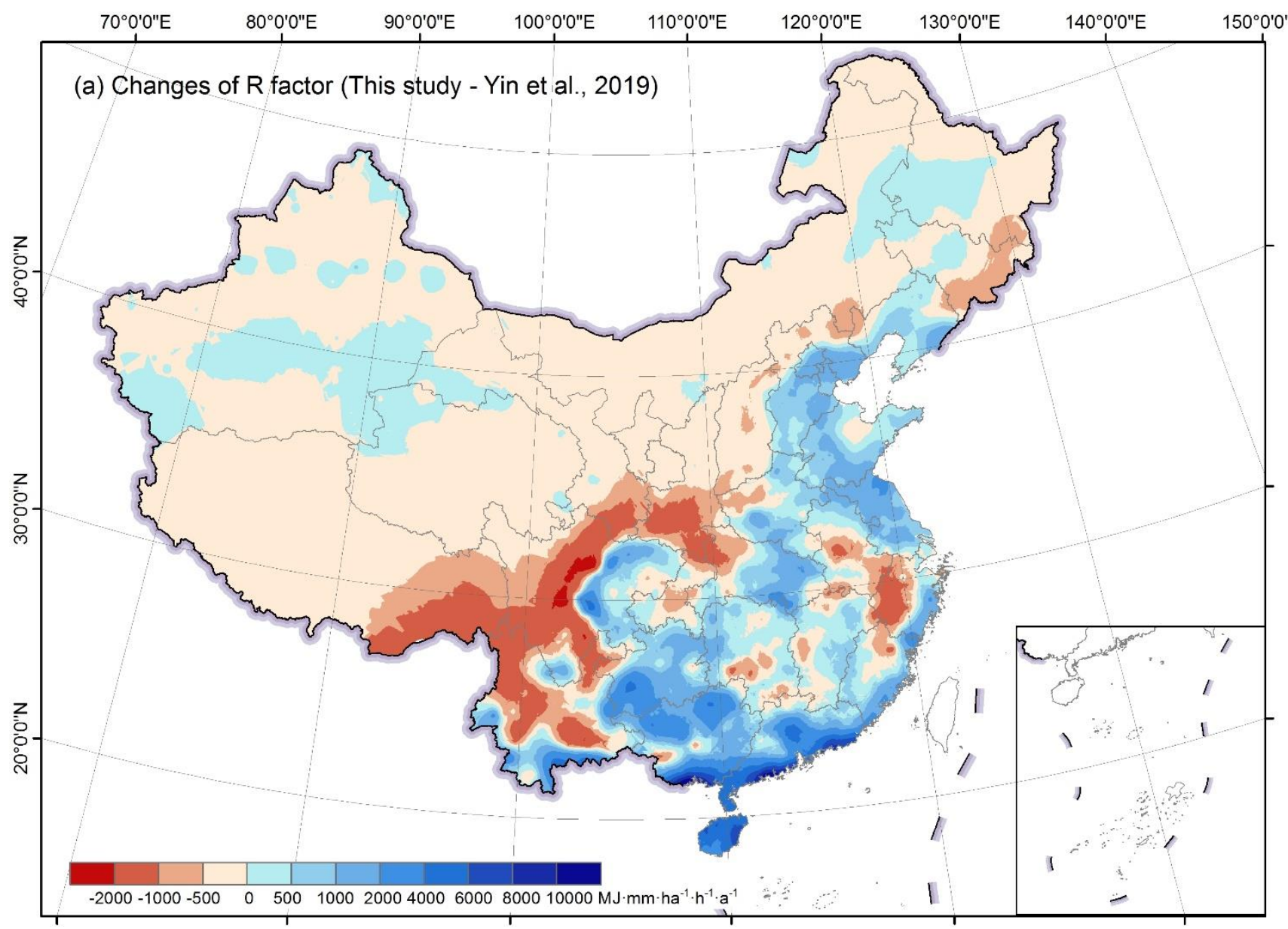




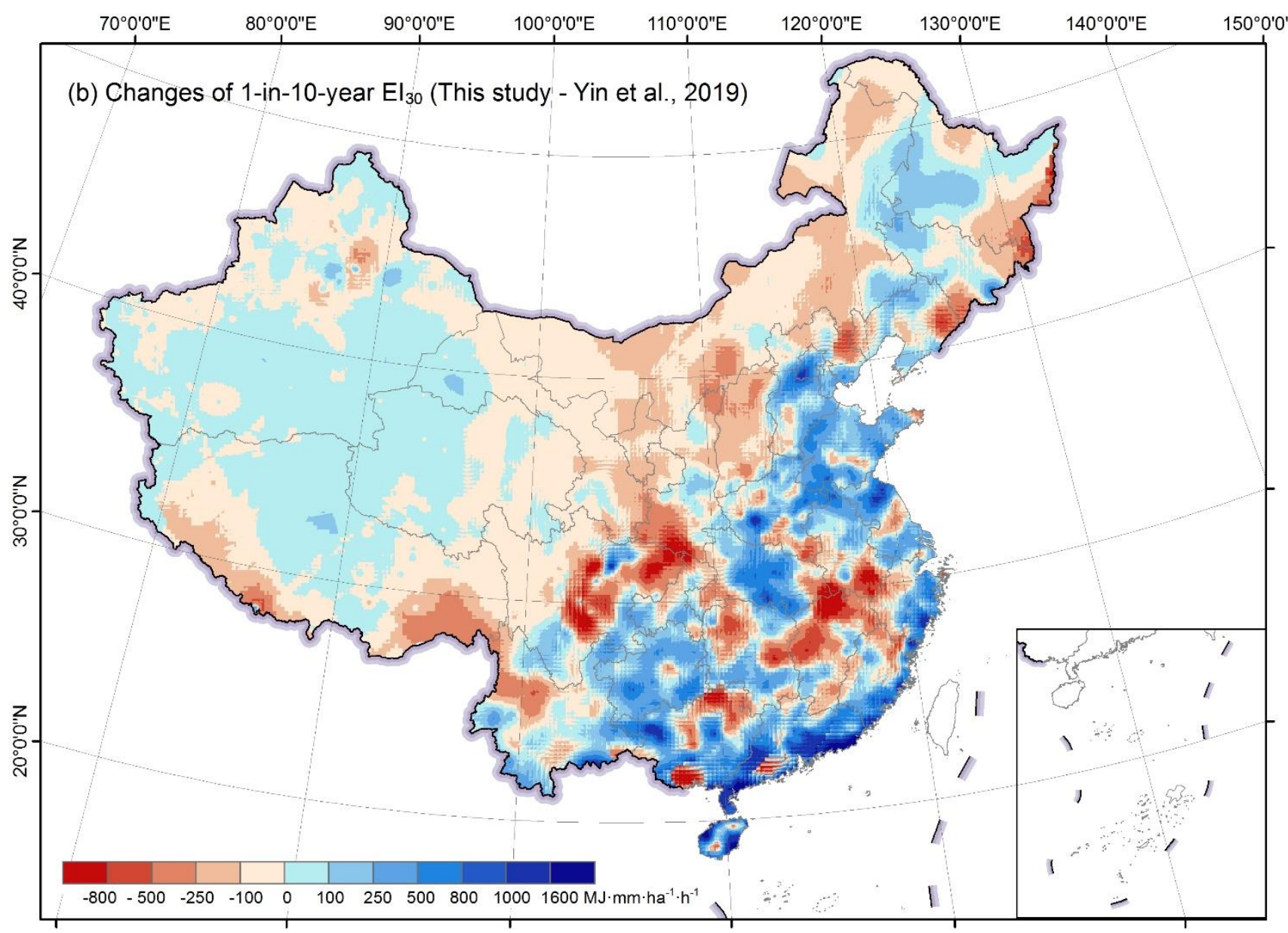

Figure 6: Changes of the $\mathrm{R}$ factor(a) and the 1-in-10-year EI30(b) comparing with the previous study

Comparing with the maps from Yin et al. (2019), the new maps can be quite different at some local areas (Fig. 6a and 6b). The

$\mathrm{R}$ factor in the new map was higher for most of the southeastern area, and lower for most of the middle and western areas, especially for the southwestern area (Fig. 6a). The change map of 1-in-10-year event $\mathrm{EI}_{30}$ demonstrated similar pattern with that of $\mathrm{R}$ factor, whereas with more negative values in some eastern mountainous areas.

\subsection{Contribution analysis on the improvement of erosivity maps}

\subsubsection{Contribution of data temporal resolution}

270 Figure 7 shows that the $\mathrm{R}$ factor estimated from daily data (Eq. 12) is underestimated when the $\mathrm{R}$ value is higher than 10000 MJ mm ha ${ }^{-1} \mathrm{~h}^{-1} \mathrm{a}^{-1}$, and slightly overestimated when the value is lower than $2000 \mathrm{MJ} \mathrm{mm} \mathrm{ha}^{-1} \mathrm{~h}^{-1} \mathrm{a}^{-1}$. The model using hourly data improved the accuracy by about $11.1 \%$ (median value of relative error) compared to that from daily data (Fig. 7). Estimated 1-in-10-year $\mathrm{EI}_{30}$ would be underestimated using hourly and daily data, and the underestimation is greater if daily 
https://doi.org/10.5194/essd-2020-370

Preprint. Discussion started: 1 March 2021

(c) Author(s) 2021. CC BY 4.0 License.

(c) (1)

data were used (Fig. 7). Unlike the $\mathrm{R}$ factor, 1-in-10-year $\mathrm{EI}_{30}$ was not noticeably improved with an increase in the temporal resolution from daily to hourly data, probably due to the fact that the 1-in-10-year $\mathrm{EI}_{30}$ values estimated using daily data in Yin et al. (2019) had already been multiplied by a conversion factor of 1.17 to correct the 1-in-10-year daily erosivity to approximate the true 1-in-10-year $\mathrm{EI}_{30}$ from 1-min data.
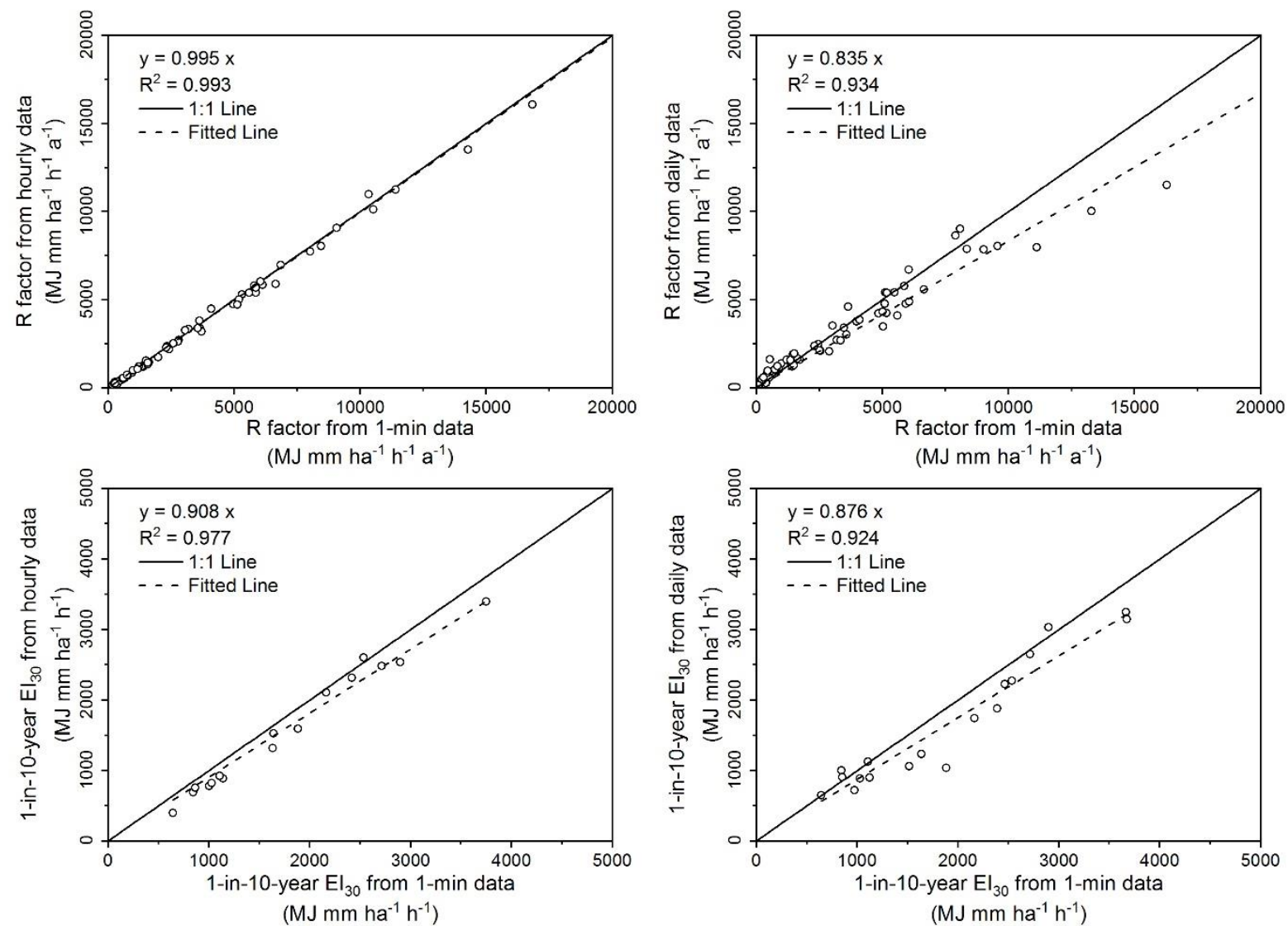

Figure 7: Comparison of the R factor (upper) and 1-in-10-year EI30 (lower) estimated from hourly (left) and daily (right) rainfall data

\subsubsection{Contribution of the station density}

Interpolation for the Western (W) region had the least NSE compared to others, which may be induced by the sparsity of stations (Fig. 1) and the lower spatial correlation of rainfall. The fitted semivariogram for the $\mathrm{R}$ factor in $\mathrm{W}$ region had a range of $35 \mathrm{~km}$, whereas the ranges for Mid-western (MW), Northeastern (NE) and Southeastern (SE) regions were 288, 261 and

$2851235 \mathrm{~km}$, respectively.

A comparison of cross-validation between the two maps with different station densities shows that the interpolation with denser stations can improve the accuracy by $2.6 \% \sim 15.4 \%$ for the R factor based on the sMAPE index, and by $1.4 \% \sim 31.8 \%$ for 1 - 
https://doi.org/10.5194/essd-2020-370

Preprint. Discussion started: 1 March 2021

(c) Author(s) 2021. CC BY 4.0 License.

(c) (1)

in-10-year $\mathrm{EI}_{30}$ (Table 3) when the station density increased. The NSE can increase by 0.016 to 0.109 for R factor. For 10 -year $\mathrm{EI}_{30}$, the NSE decreased in region $\mathrm{W}, \mathrm{MW}$ and $\mathrm{SE}$, and increased by 0.038 in region NE.

290 For the R factor, in region $\mathrm{W}$, the station density doubled (increased from 36.6 to $21.210^{3} \mathrm{~km}^{2} 1$ station), and the accuracy improved by $15.4 \%$, whereas the sMAPE of $53.3 \%$ was still high with this increase in station density. In region MW, the station density tripled (from 13.9 to $4.810^{3} \mathrm{~km}^{2} 1$ station) and the accuracy was improved by $11.1 \%$ based on the sMAPE index from $30.7 \%$ to $19.6 \%$. In region NE and SE, the station density tripled and quadrupled, respectively, and the accuracy increased about $2.5 \%$. For 1-in-10-year $\mathrm{EI}_{30}$, the improvement for the 1-in-10-year $\mathrm{EI}_{30}$ was even more (by $31.8 \%$ in region $\mathrm{W}$ and $19.6 \%$ in region MW). The improvement was mainly in western regions, and the station density in the eastern China before the increase is enough to describe the spatial variation of the $\mathrm{R}$ factor and the 1-in-10-year $\mathrm{EI}_{30}$. It can be inferred that when there were less than about $10 \cdot 10^{3} \mathrm{~km}^{2} 1$ station, the increasing of the site density has little impact on the improvement of the interpolation (Fig. 8).

Table 3: Comparison of cross-validation results for erosivity maps interpolated based on data from 774 and 2381 stations

\begin{tabular}{|c|c|c|c|c|c|c|}
\hline \multirow{2}{*}{ Region } & \multirow{2}{*}{ No. of the stations } & \multirow{2}{*}{$\begin{array}{l}\text { Density of the stations }\left(10^{3} \mathrm{~km}^{2}\right. \\
1 \text { station })\end{array}$} & \multicolumn{2}{|c|}{$\mathrm{R}$ factor } & \multicolumn{2}{|c|}{ 1-in-10-year $\mathrm{EI}_{30}$} \\
\hline & & & sMAPE & NSE & sMAPE & NSE \\
\hline \multirow[t]{2}{*}{$\mathrm{W}$} & 87 & 36.6 & $68.7 \%$ & 0.489 & $63.7 \%$ & 0.389 \\
\hline & 150 & 21.2 & $53.3 \%$ & 0.599 & $31.8 \%$ & 0.293 \\
\hline \multirow[t]{2}{*}{ MW } & 161 & 13.9 & $30.7 \%$ & 0.938 & $44.0 \%$ & 0.887 \\
\hline & 471 & 4.8 & $19.6 \%$ & 0.951 & $24.5 \%$ & 0.886 \\
\hline \multirow[t]{2}{*}{$\mathrm{NE}$} & 214 & 11.0 & $12.4 \%$ & 0.946 & $17.0 \%$ & 0.857 \\
\hline & 690 & 3.4 & $9.7 \%$ & 0.962 & $14.9 \%$ & 0.895 \\
\hline \multirow[t]{2}{*}{ SE } & 389 & 6.6 & $10.9 \%$ & 0.942 & $15.5 \%$ & 0.844 \\
\hline & 1362 & 1.9 & $8.3 \%$ & 0.959 & $14.0 \%$ & 0.824 \\
\hline
\end{tabular}



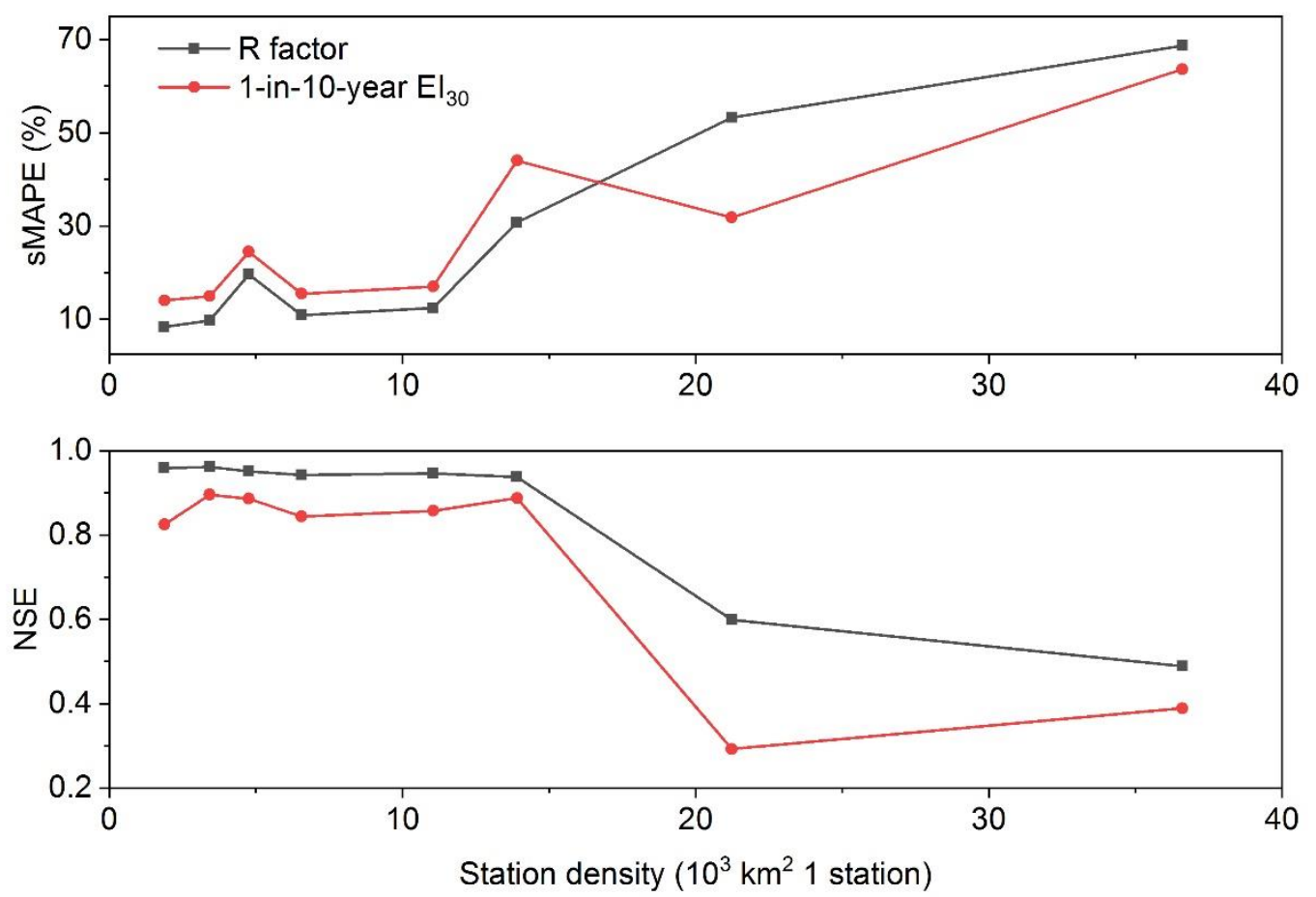

Figure 8: Improvement of the interpolation with the increase of station density. Data were from the 774 and 2381 stations in the 4 different regions

\subsubsection{Contribution of the interpolation method}

For the R factor, cross-validation of Ordinary Kriging and Universal Kriging with the mean annual rainfall as the co-variable

(Table 4) shows that UK improved the interpolation accuracy by 2.3\%-9.0\% (sMAPE) compared to OK. In the western region, the NSE increased from $0.285(\mathrm{OK})$ to $0.599(\mathrm{UK})$. Therefore, it is better to use UK instead of OK when generating the R factor map, especially in western China where station density was low. For 1-in-10-year $\mathrm{EI}_{30}$, UK improved the accuracy by $0.4 \%$ 9.7\% (sMAPE). In region $\mathrm{W}$, the accuracy improved by $9.7 \%$ and the NSE increased from 0.094(OK) to 0.293(UK).

Table 4: Cross-validation results of interpolation of $\mathrm{R}$ factor and 10 -year $\mathrm{EI}_{30}$ using OK and UK

\begin{tabular}{cccccc}
\hline \multirow{2}{*}{ Region } & \multirow{2}{*}{ Interpolation method } & \multicolumn{2}{c}{ R factor } & \multicolumn{2}{c}{ 1-in-10-year $\mathrm{EI}_{30}$} \\
\cline { 3 - 6 } & & sMAPE & NSE & sMAPE & NSE \\
\hline \multirow{2}{*}{$\mathrm{W}$} & OK & $62.3 \%$ & 0.285 & $41.5 \%$ & 0.094 \\
& UK & $53.3 \%$ & 0.599 & $31.8 \%$ & 0.293 \\
\hline \multirow{2}{*}{ MW } & OK & $24.8 \%$ & 0.861 & $24.9 \%$ & 0.838 \\
& UK & $19.6 \%$ & 0.951 & $24.5 \%$ & 0.886 \\
\hline \multirow{2}{*}{$\mathrm{NE}$} & OK & $12.0 \%$ & 0.926 & $16.5 \%$ & 0.865 \\
& UK & $9.7 \%$ & 0.962 & $14.9 \%$ & 0.895 \\
\hline
\end{tabular}


https://doi.org/10.5194/essd-2020-370

Preprint. Discussion started: 1 March 2021

(c) Author(s) 2021. CC BY 4.0 License.

\begin{tabular}{cccccc}
\hline \multirow{2}{*}{ Region } & \multirow{2}{*}{ Interpolation method } & \multicolumn{2}{c}{$\mathrm{R}$ factor } & \multicolumn{2}{c}{ 1-in-10-year $\mathrm{EI}_{30}$} \\
\cline { 3 - 6 } & & sMAPE & NSE & sMAPE & NSE \\
\hline \multirow{2}{*}{$\mathrm{SE}$} & OK & $11.2 \%$ & 0.911 & $14.8 \%$ & 0.844 \\
& UK & $8.3 \%$ & 0.959 & $14.0 \%$ & 0.824 \\
\hline
\end{tabular}

\section{Discussion}

This study produced quality $\mathrm{R}$ factor and 1-in-10-year $\mathrm{EI}_{30}$ maps with hourly data from 2381 stations over mainland China. The improvement of the $\mathrm{R}$ factor map over previously published $\mathrm{R}$ factor map can be contributed to the increase in the temporal resolution from daily to hourly data, whereas that of 1-in-10-year $\mathrm{EI}_{30}$ map to the increase of the station density in comparison with those of Yin et al. (2019). There are mainly two reasons for this. First, 1-in-10-year event $\mathrm{EI}_{30}$ values estimated from the daily data had already been adjusted to those from the 1-min data by multiplying a conversion factor of 1.17 (Yin et al., 2019), which resulted in no obvious improvement from the daily data to hourly data. Second, the 1-in-10-year event $\mathrm{EI}_{30}$ associated with extreme rainfall event intrinsically has a high spatial variability in comparison to the annual average rainfall erosivity as shown in Table 3. The accuracy of spatially interpolated rainfall erosivity was more sensitive to the station density when the station density is low. Hence the improvement of the map of the 1-in-10-year $\mathrm{EI}_{30}$ was mainly contributed to the increase of the station density, especially for the western and the mid-western regions with sparse station density.

Panagos et al. (2017) developed a Global Rainfall Erosivity Database with hourly and sub-hourly rainfall data from 3625 stations over 63 countries, for water erosion assessment for many regions of the world especially where observational data were limited. In their study, rainfall data at 60-min interval from 387 stations across China were used. Figure 9 shows that the $\mathrm{R}$ factor for China extracted from Panagos et al. (2017) is systematically underestimated by about $30 \%$ for most areas in China, whereas overestimated in the Tibetan Plateau (cf. Fig. 5a). The reason for the underestimation may be that the R factor calculated from 60-min interval data applied a conversion factor $\left(\mathrm{CF}_{30}\right)$ that was developed from the values estimated by 60 min data to those by 30-min data in Panagos et al. (2015), rather than a factor to those by breakpoint data $\left(\mathrm{CF}_{\mathrm{bp}}\right)$ or 1-min data $\left(\mathrm{CF}_{1}\right)$, which were used in USLE (Wischmeier and Smith, 1965, 1978), RUSLE (Renard, 1997) and this study. Previous research have showed the difference between $\mathrm{CF}_{30}$ and $\mathrm{CF}_{\mathrm{bp}}\left(\mathrm{CF}_{1}\right)$ can result in an underestimation of $\mathrm{R}$ factor by about $20 \%$ (Auerswald et al., 2015; Yue et al., 2020). Table 5 shows that the relative error of the map from Panagos et al. (2017) could reduce by about $6.2 \%$ after multiplying by a conversion factor of 1.253 , which was calibrated by (Yue et al., 2020) for converting the $\mathrm{R}$ factor from 30-min data to 1-min data. The adjusted map still generally underestimated. The reason may be that the equation for estimating the storm energy (E) used in Panagos et al. (2017) was from RUSLE (Renard, 1997), which have been reported an underestimation of the storm energy up to 10\% in previous studies (McGregor et al., 1995; Yin et al., 2017). Because of this, the equation for estimating the storm energy (E) in RUSLE (Renard, 1997) was then modified in RUSLE2 (USDA-ARS, 2013), which was adopted in this study.

The R factor in the Tibetan Plateau varies from 0 to $12326 \mathrm{MJ} \mathrm{mm} \mathrm{ha}^{-1} \mathrm{~h}^{-1} \mathrm{a}^{-1}$ in Panagos et al. (2017), and from 4.6 to 4441.9 MJ mm ha ${ }^{-1} \mathrm{~h}^{-1} \mathrm{a}^{-1}$ in this study. The former was derived from a Gaussian Process Regression (GPR) model and a number of 
https://doi.org/10.5194/essd-2020-370

Preprint. Discussion started: 1 March 2021

(c) Author(s) 2021. CC BY 4.0 License.

(c) (i)

monthly climate variables from the WorldClim database, such as the mean monthly precipitation, mean minimum, average and maximum monthly temperature. The GPR model was calibrated using the site-specific $\mathrm{R}$ factor values and these climate variables, which may not applicable for sites at high altitude, as none of the sites was located in the Tibetan Plateau region. The GPR model might be the main reason for the overestimation of the R factor in the Tibetan Plateau where the R factor was expected to be underestimated just like any other regions.
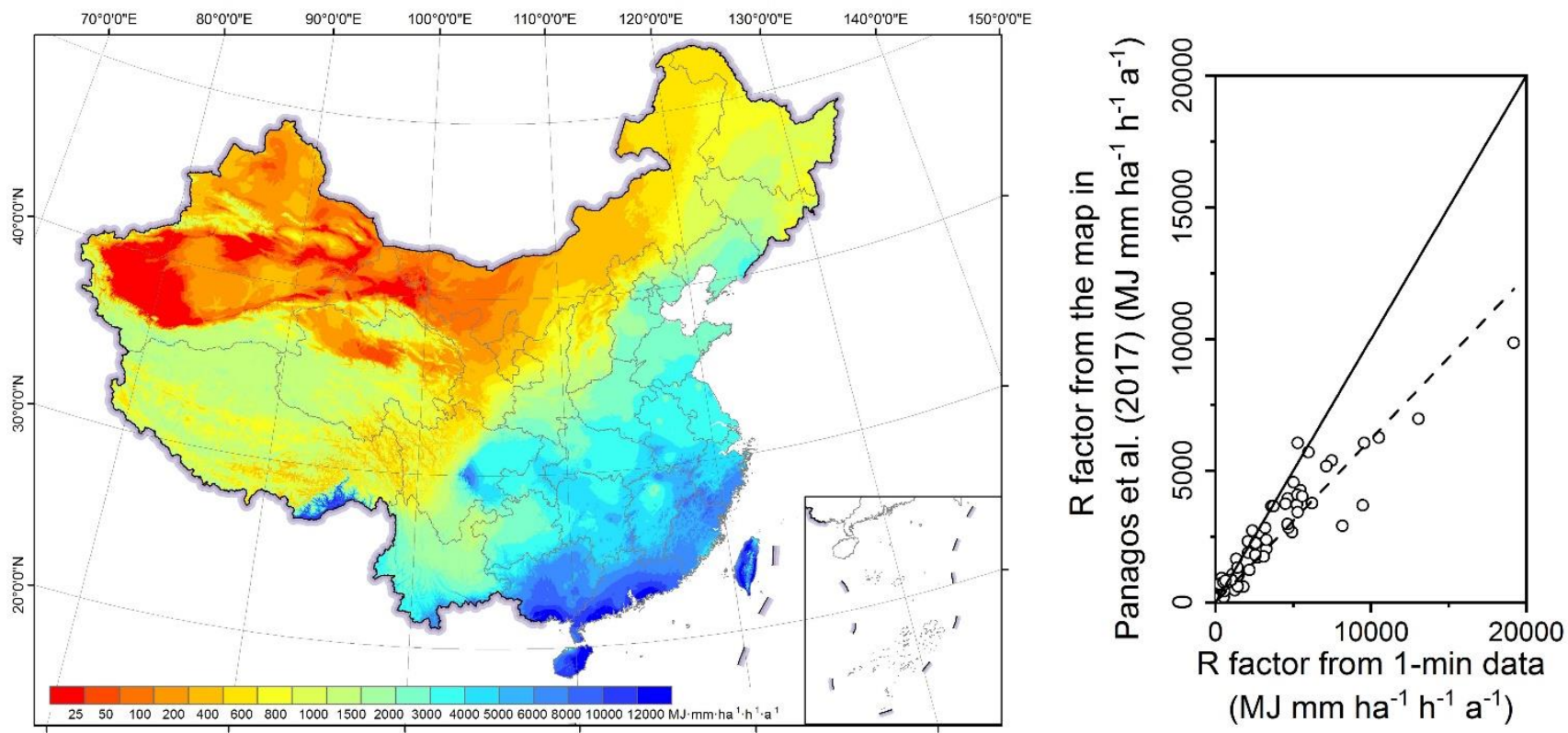

345 Figure 9: $\mathbf{R}$ factor map for China extracted from Panagos et al. (2017) and the evaluation of the map based on 62 stations with 1min data.

Table 5: Comparison of the statistical characteristics of the relative errors of the $\mathbf{R}$ factor from maps generated in this study and extracted from Panagos et al. (2017) (original and adjusted). The adjusted map of Panagos et al. (2017) was the original map multiplying by a conversion factors of 1.253, which was calibrated by Yue et al. (2020) for converting the $R$ factor from 30-min data to 1-min data.

\begin{tabular}{cccc}
\hline & This study & Panagos et al. (2017) & Panagos et al. (2017) adjusted \\
\hline $25^{\text {th }}$ percentile & $7.1 \%$ & $14.8 \%$ & $10.4 \%$ \\
Median & $16.1 \%$ & $28.3 \%$ & $22.1 \%$ \\
$75^{\text {th }}$ percentile & $28.0 \%$ & $40.5 \%$ & $43.2 \%$ \\
Mean & $20.1 \%$ & $33.8 \%$ & $33.1 \%$ \\
\hline
\end{tabular}

\section{Conclusions}

This study generated the R factor and 1-in-10-year $\mathrm{EI}_{30}$ maps using hourly rainfall data for the period from 1951 to 2018 from 
https://doi.org/10.5194/essd-2020-370

Preprint. Discussion started: 1 March 2021

(c) Author(s) 2021. CC BY 4.0 License.

(c) (i)

maps (maps from Yin et al. (2019) were taken as references) in terms of temporal resolution of the rainfall data, the station density, and the interpolation method. The conclusions were drawn as follows:

(1) Comparing with the current maps for the 62 reference sites, the R factor map generated in this study improved the accuracy from $19.4 \%$ to $15.9 \%$ in the mid-western and eastern regions, $45.2 \%$ to $21.6 \%$ in the western region, and the 1-in-10-year $\mathrm{EI}_{30}$ map improved the accuracy from $21.7 \%$ to $13.0 \%$ in the mid-western and eastern regions.

(2) The $\mathrm{R}$ factor and the 1-in-10-year $\mathrm{EI}_{30}$ increased from the northwestern to the southeastern China. The $\mathrm{R}$ factor was from 0 to $25300 \mathrm{MJ} \mathrm{mm} \mathrm{ha}^{-1} \mathrm{~h}^{-1} \mathrm{a}^{-1}$, and the 1-in-10-year $\mathrm{EI}_{30}$ was from 0 to $11246 \mathrm{MJ} \mathrm{mm} \mathrm{ha}^{-1} \mathrm{~h}^{-1}$. Comparing with the current maps, the $\mathrm{R}$ factor and 1-in-10-year event $\mathrm{EI}_{30}$ in the new maps were higher for most of the southeastern area, and lower for most of the middle and western areas.

365 (3) The improvement of the $\mathrm{R}$ factor map can be mainly contributed to the increase of the temporal resolution from daily to hourly, whereas that of 1-in-10-year $\mathrm{EI}_{30}$ map to the increase of station density. The increased station density mainly improved the accuracy in the western regions for both the $\mathrm{R}$ factor and 1-in-10-year $\mathrm{EI}_{30}$. The contribution of increasing the station density to improve the interpolation was limited when the station density was denser than about $10 \cdot 10^{3} \mathrm{~km}^{2} 1$ station. As for the interpolation method, Universal Kriging with the mean annual rainfall as the co-variable performed better than Ordinary Kriging for all regions, especially for the western regions.

\section{Data availability}

The Rainfall erosivity maps ( $\mathrm{R}$ factor and 1-in-10-year $\mathrm{EI}_{30}$ ) are available at: https://dx.doi.org/10.12275/bnu.clicia.rainfallerosivity.CN.001 (Yue et al., 2020)

\section{Competing interests}

375 The authors declare that they have no conflict of interest.

\section{Acknowledgments}

This work was supported by National Key R\&D Program (no.2018YFC0507006) and the National Natural Science Foundation of China (no. 41877068). We also would like to thank the high-performance computing support from the Center for Geodata and Analysis, Faculty of Geographical Science, Beijing Normal University [https://gda.bnu.edu.cn/]

\section{References}

Alewell, C., Borelli, P., Meusburger, K. and Panagos, P.: Using the USLE: Chances, challenges and limitations of soil erosion modelling, Int. soil water Conserv. Res., 7(3), 203-225, doi:10.1016/j.iswcr.2019.05.004, 2019. 
https://doi.org/10.5194/essd-2020-370

Preprint. Discussion started: 1 March 2021

(c) Author(s) 2021. CC BY 4.0 License.

(c) (i)

Angulomartínez, M. and Beguería, S.: Estimating rainfall erosivity from daily precipitation records: a comparison among methods using data from the Ebro Basin (NE Spain), J. Hydrol., 379(1-2), 111-121, doi:10.1016/j.jhydrol.2009.09.051, 3852009.

Arnoldus, H. M. J.: Methodology used to determine the maximum potential average annual soil loss due to sheet and rill erosion in Morocco, FAO Soils Bull., doi:10.1038/35106674, 1977.

Auerswald, K., Fiener, P., Gomez, J. A., Govers, G., Quinton, J. N. and Strauss, P.: Comment on "Rainfall erosivity in Europe” by Panagos et al.(Sci. Total Environ., 511, 801-814, 2015), Sci. Total Environ., 532, 849-852, doi:10.1016/j.scitotenv.2015.05.019, 2015.

Bagarello, V. and D'Asaro, F.: Estimating single storm erosion index, Trans. ASAE, 37(3), 785-791, doi:10.13031/2013.28141, 1994.

Bonilla, C. A. and Vidal, K. L.: Rainfall erosivity in central Chile, J. Hydrol., 410(1-2), 126-133, doi:10.1016/j.jhydrol.2011.09.022, 2011.

395 Borrelli, P., Diodato, N. and Panagos, P.: Rainfall erosivity in Italy: a national scale spatiotemporal assessment, Int. J. Digit. Earth, 9(9), 835-850, doi:10.1080/17538947.2016.1148203, 2016.

Borrelli, P., Robinson, D. A., Fleischer, L. R., Lugato, E., Ballabio, C., Alewell, C., Meusburger, K., Modugno, S., Schütt, B. and Ferro, V.: An assessment of the global impact of 21st century land use change on soil erosion, Nat. Commun., 8(1), 1-13, doi:10.1038/s41467-017-02142-7, 2017.

400 Capolongo, D., Diodato, N., Mannaerts, Cm., Piccarreta, M. and Strobl, R. O.: Analyzing temporal changes in climate erosivity using a simplified rainfall erosivity model in Basilicata (southern Italy), J. Hydrol., 356(1-2), 119-130, doi:10.1016/j.jhydrol.2008.04.002, 2008.

Coles, S. G.: An introduction to statistical modeling of extreme values, Springer., 2001.

FAO: Outcome document of the Global Symposium on Soil Erosion, FAO, Rome. [online] Available from:

405 http://www.fao.org/3/ca5697en/ca5697en.pdf, 2019a.

FAO: Soil erosion: the greatest challenge to sustainable soil management, FAO, Rome. [online] Available from: http://www.fao.org/3/ca4395en/ca4395en.pdf, 2019b.

Ferrari, R., Pasqui, M., Bottai, L., Esposito, S. and Di Giuseppe, E.: Assessment of soil erosion estimate based on a high temporal resolution rainfall dataset, in Proc. 7th European Conference on Applications of Meteorology (ECAM), Utrecht,

410 Netherlands, pp. 12-16., 2005.

Ferro, V., Giordano, G. and Iovino, M.: Isoerosivity and erosion risk map for Sicily, Hydrol. Sci. J., 36(6), 549-564, doi:10.1080/02626669109492543, 1991.

Grimm, M., Jones, R. and Montanarella, L.: Soil erosion risk in Europe, Joint Research Centre, European Commission., 2001.

415 Haith, D. A. and Merrill, D. E.: Evaluation of a daily rainfall erosivity model, Trans. ASAE, 30(1), 90-93, doi:10.13031/2013.30407, 1987. 
https://doi.org/10.5194/essd-2020-370

Preprint. Discussion started: 1 March 2021

(c) Author(s) 2021. CC BY 4.0 License.

Hosking, J. R. M.: L-Moments: Analysis and Estimation of Distributions Using Linear Combinations of Order Statistics, J. R. Stat. Soc., 52(1), 105-124, doi:10.2307/2345653, 1990.

Klik, A., Haas, K., Dvorackova, A. and Fuller, I. C.: Spatial and temporal distribution of rainfall erosivity in New Zealand,

Soil Res., 40(6), 887-901, doi:10.1071/sr01117, 2015.

Lee, J.-H. and Heo, J.-H.: Evaluation of estimation methods for rainfall erosivity based on annual precipitation in Korea, J. Hydrol., 409(1-2), 30-48, doi:10.1016/j.jhydrol.2011.07.031, 2011.

Li, T., Zheng, X., Dai, Y., Yang, C., Chen, Z., Zhang, S., Wu, G., Wang, Z., Huang, C. and Shen, Y.: Mapping near-surface air temperature, pressure, relative humidity and wind speed over Mainland China with high spatiotemporal resolution, Adv. Atmos. Sci., 31(5), 1127-1135, doi:10.1007/s00376-014-3190-8, 2014.

Liu Guo, S., Li, Z., Xie, Y., Zhang, K., Liu, X., B.: Sample survey of water erosion in China (in Chinese), Soil Water Conserv. China, 10, 26-34, doi:10.14123/j.cnki.swcc.2013.10.010, 2013.

Liu, B., Tao, H. and Song, C.: Temporal and spatial variations of rainfall erosivity in China during 1960 to 2009, Geogr. Res., 32(2), 245-256, doi:10.11821/yj2013020005, 2013.

430 Liu, Y., Zhao, W., Liu, Y. and Pereira, P.: Global rainfall erosivity changes between 1980 and 2017 based on an erosivity model using daily precipitation data, Catena, 194, 104768, doi:10.1016/j.catena.2020.104768, 2020.

Lu, H. and Yu, B.: Spatial and seasonal distribution of rainfall erosivity in Australia, Soil Res., 40(6), 887-901, doi:10.1071/sr01117, 2002.

Lu, H., Gallant, J., Prosser, I. P., Moran, C. and Priestley, G.: Prediction of sheet and rill erosion over the Australian 435 continent, incorporating monthly soil loss distribution, L. Water Tech. Report. CSIRO, Canberra, Aust., 2001. McGregor, K. C., Bingner, R. L., Bowie, A. J. and Foster, G. R.: Erosivity index values for northern Mississippi, Trans. ASAE, 38(4), 1039-1047, doi:10.13031/2013.27921, 1995.

Naipal, V., Reick, C. H., Pongratz, J. and Van Oost, K.: Improving the global applicability of the RUSLE model-adjustment of the topographical and rainfall erosivity factors, Geosci. Model Dev., 8, 2893-2913, doi:10.5194/gmdd-8-2991-2015, 4402015.

Oliveira, P. T. S., Rodrigues, D. B. B., Sobrinho, T. A., Carvalho, D. F. De and Panachuki, E.: Spatial variability of the rainfall erosive potential in the State of Mato Grosso do Sul, Brazil, Eng. Agrícola, 32(1), 69-79, doi:10.1590/S010069162012000100008, 2012.

Panagos, P., Ballabio, C., Borrelli, P., Meusburger, K., Klik, A., Rousseva, S., Tadić, M. P., Michaelides, S. and 445 Hrabalíková, M.: Rainfall erosivity in Europe, Sci. Total Environ., 511, 801-814, doi:10.1016/j.scitotenv.2015.01.008, 2015a.

Panagos, P., Borrelli, P., Poesen, J., Ballabio, C., Lugato, E., Meusburger, K., Montanarella, L. and Alewell, C.: The new assessment of soil loss by water erosion in Europe, Environ. Sci. Policy, 54, 438-447, doi:10.1016/j.envsci.2015.08.012, $2015 b$. 
https://doi.org/10.5194/essd-2020-370

Preprint. Discussion started: 1 March 2021

(c) Author(s) 2021. CC BY 4.0 License.

450 Panagos, P., Ballabio, C., Borrelli, P. and Meusburger, K.: Spatio-temporal analysis of rainfall erosivity and erosivity density in Greece, Catena, 137, 161-172, doi:10.1016/j.catena.2015.09.015, 2016.

Panagos, P., Borrelli, P., Meusburger, K., Yu, B., Klik, A., Lim, K. J., Yang, J. E., Ni, J., Miao, C. and Chattopadhyay, N.: Global rainfall erosivity assessment based on high-temporal resolution rainfall records, Sci. Rep., 7(1), 4175, doi:10.1038/s41598-017-04282-8, 2017.

455 Porto, P.: Exploring the effect of different time resolutions to calculate the rainfall erosivity factorRin Calabria, southern Italy, Hydrol. Process., 30(10), 1551-1562, doi:10.1002/hyp.10737, 2016.

Qin, W., Guo, Q., Zuo, C., Shan, Z., Ma, L. and Sun, G.: Spatial distribution and temporal trends of rainfall erosivity in mainland China for 1951-2010, Catena, 147, 177-186, doi:10.1016/j.catena.2016.07.006, 2016.

Ramos, M. C. and Durán, B.: Assessment of rainfall erosivity and its spatial and temporal variabilities: Case study of the

460 Penedès area (NE Spain), Catena, 123, 135-147, doi:10.1016/j.catena.2014.07.015, 2014.

Renard, K. G. and Freimund, J. R.: Using monthly precipitation data to estimate the R-factor in the revised USLE, J.

Hydrol., 157(1-4), 287-306, doi:10.1016/0022-1694(94)90110-4, 1994.

Renard, K. G., Foster, G. R., Weesies, G. A., Mccool, D. K. and Yoder, D. C.: Predicting soil erosion by water: a guide to conservation planning with the Revised Universal Soil Loss Equation (RUSLE), U.S. Department of Agriculture,

465 Agricultural Handbook No.703, Washington, D.C., 1997.

Richardson, C. W., Foster, G. R. and Wright, D. A.: Estimation of erosion index from daily rainfall amount, Trans. ASAE, 26(1), 153-156, doi:10.13031/2013.33893, 1983.

Sadeghi, S. H., Zabihi, M., Vafakhah, M. and Hazbavi, Z.: Spatiotemporal mapping of rainfall erosivity index for different return periods in Iran, Nat. Hazards, 87(1), 35-56, doi:10.1007/s11069-017-2752-3, 2017.

470 Selker, J. S., Haith, D. A. and Reynolds, J. E.: Calibration and testing of a daily rainfall erosivity model, , 33(5), 1612, doi:10.13031/2013.31516, 1990.

Sheridan, J. M., Davis, F. M., Hester, M. L. and Knisel, W. G.: Seasonal distribution of rainfall erosivity in peninsular Florida, Trans. ASAE, 32(5), 1555-1560, doi:10.13031/2013.31189, 1989.

USDA-ARS: Science documentation: Revised Universal Soil Loss Equation Version 2 (RUSLE2), USDA-Agricultural

475 Research Service, Washington, D.C., 2013.

Wang, W., Jiao, J., Hao, X., Zhang, Xiankui and Lu, X.: Distribution of rainfall erosivity R value in China, J. Soil Eros.

Soil Conserv., (1), 1, 1996.

Wischmeier, W. H.: A Rainfall Erosion Index for a Universal Soil-Loss Equation 1, Proc Soil Sci. Soc. Am., 23(3), 246249, doi:10.2136/sssaj1959.03615995002300030027x, 1959.

480 Wischmeier, W. H. and Smith, D. D.: Rainfall energy and its relationship to soil loss, Trans.am.gephys.union, 39(2), 285291, doi:10.1029/TR039i002p00285, 1958.

Wischmeier, W. H. and Smith, D. D.: Predicting rainfall-erosion losses from cropland east of the Rocky Mountains: Guide for selection of practices for soil and water conservation, US Department of Agriculture, Washington, D.C., 1965. 
https://doi.org/10.5194/essd-2020-370

Preprint. Discussion started: 1 March 2021

(c) Author(s) 2021. CC BY 4.0 License.

(c) (i)

Wischmeier, W. H. and Smith, D. D.: Predicting rainfall erosion losses: a guide to conservation planning, Department of Agriculture, Science and Education Administration, Washington, D.C., 1978.

Xie, Y., Liu, B. Y. and Zhang, W. B.: Study on standard of erosive rainfall, J. soil water Conserv., 14(4), 6-11, doi:10.13870/j.cnki.stbcxb.2000.04.002, 2000.

Xie, Y., Yin, S. Q., Liu, B. Y., Nearing, M. A. and Zhao, Y.: Models for estimating daily rainfall erosivity in China, J. Hydrol., 535, 547-558, doi:10.1016/j.jhydrol.2016.02.020, 2016.

490 Yang, X. and Yu, B.: Modelling and mapping rainfall erosivity in New South Wales, Australia, Soil Res., 53(2), 178-189, doi:10.1071/SR14188, 2015.

Yin, S., Xie, Y., Liu, B. and Nearing, M. A.: Rainfall erosivity estimation based on rainfall data collected over a range of temporal resolutions., Hydrol. Earth Syst. Sci. Discuss., 19(10), 4113-4126, doi:10.5194/hess-19-4113-2015, 2015.

Yin, S., Nearing, M. A., Borrelli, P. and Xue, X.: Rainfall Erosivity: An Overview of Methodologies and Applications,

495 Vadose Zo. J., 16(12), doi:10.2136/vzj2017.06.0131, 2017.

Yin, S., Xue, X., Yue, T., Xie, Y. and Gao, G.: Spatiotemporal distribution and return period of rainfall erosivity in China(in Chinese), Trans. Chinese Soc. Agric. Eng., 35(9), 105-113, doi:10.11975/j.issn.1002-6819.2019.09.013, 2019.

Yu, B. and Rosewell, C. J.: Rainfall erosivity estimation using daily rainfall amounts for South Australia, Soil Res., 34(5), 721-733, doi:10.1071/sr9960721, 1996a.

500 Yu, B. and Rosewell, C. J.: Technical notes: a robust estimator of the R-factor for the universal soil loss equation, Trans. ASAE, 39(2), 559-561, doi:10.13031/2013.27535, 1996b.

Yu, B., Rosewell, C. J., Yu, B. and Rosewell, C. J.: An assessment of a daily rainfall erosivity model for New South Wales, Aust. J. Soil Res., 34(1), 139-152, doi:10.1071/SR9960139, 1996.

Yue, T., Xie, Y., Yin, S., Yu, B., Miao, C. and Wang, W.: Effect of time resolution of rainfall measurements on the erosivity

505 factor in the USLE in China, Int. soil water Conserv. Res., doi:https://doi.org/10.1016/j.iswcr.2020.06.001, 2020.

Yue, T., Yin, S., Xie, Y., Yu, B., Liu, B. Rainfall erosivity mapping over mainland China based on high density hourly rainfall records, doi: https://dx.doi.org/10.12275/bnu.clicia.rainfallerosivity.CN.001, 2020.

Zhang, W., Xie, Y. and Liu, B.: Spatial distribution of rainfall erosivity in China, J. Mt. ence, 21(1), 33-40, doi:10.16089/j.cnki.1008-2786.2003.01.005, 2003.

510 Zhang, W. B., Xie, Y. and Liu, B. Y.: Rainfall Erosivity Estimation Using Daily Rainfall Amounts, Sci. Geogr. Sin., 22(6), 705-711, doi:10.13249/j.cnki.sgs.2002.06.012, 2002.

Zhu, Z. and Yu, B.: Validation of Rainfall Erosivity Estimators for Mainland China, Trans. ASABE, 58(1), 61-71, doi:10.13031/trans.58.10451, 2015. 